\title{
Synthesis, in silico Studies, and Anticonvulsant Activity of 1,3,4-Oxadiazole Derivatives
}

\section{Banylla Felicity Dkhar Gatphoh, Natasha Naval Aggarwal, Merugumolu Vijay Kumar and Bistuvalli Chandrashekharappa Revanasiddappa*}

\author{
Department of Pharmaceutical Chemistry, NGSM Institute of Pharmaceutical Sciences of Nitte, \\ Deemed to be University, Mangalore, Karnataka 575018, India
}

('Corresponding author's e-mail: revan@nitte.edu.in)

Received: 15 February 2021, Revised: 9 June 2021, Accepted: 15 June 2021

\begin{abstract}
The title compounds 1,3,4-oxadiazole derivatives (C1-C5) were synthesized by the cyclization of 4hydroxy benzhydrazide (1) with various substituted aromatic aldehydes (2) in the presence of ceric ammonium nitrate. The structures of the newly synthesized compounds were established based on FT-IR, ${ }^{1} \mathrm{H}-\mathrm{NMR}$, and Mass spectral data. In silico analysis was carried out using the Schrodinger 2018-3 suite device Maestro and docked to the binding site of the Human GABAA receptor (PDB ID:4COF). The toxicity of the compounds was predicted using the LAZAR (Lazy structure-activity relationship) program. The invivo anticonvulsant study was performed by means of a maximal electroshock test and pentylenetetrazole (PTZ)-induced seizures. Compounds C4\&C5 showed the highest docking score of -5.676 and -5.277 , respectively, and compounds $\mathbf{C 4} \& \mathbf{C 5}$ showed the most increased in vivo anticonvulsant activity when compared with the reference drugs in both the PTZ and MES test methods.
\end{abstract}

Keywords: 1,3,4-oxadiazole, Anticonvulsant activity, GABAA receptor, Molecular docking

\section{Introduction}

1,3,4-Oxadiazoles are heterocyclic compounds with an oxygen atom and 2 nitrogen atoms at the third and fourth positions, and they are found to be an important class of compounds in pharmaceutical chemistry because of their potential pharmacophore with diverse biological activities [1]. They have been reported for various activities such as anti-inflammatory [2], anticonvulsant [3], antimicrobial [4], ulcerogenic [5], anti-HIV [6], antifungal [7], anticancer [8], antihypertensive [9], antitubercular [10] and analgesic [11] etc.

Drugs available therapeutically containing this heterocyclic nucleus are Zibotentan used as an anticancer agent [12], Fenadiazole as a hypnotic agent [13], Raltegravir as an HIV-integrase inhibitor drug [14], Furamizole as an antibacterial agent [15] and Tiodazosin as an alpha1-adrenergic antagonist [16].

Many works of literature report the presence of toxophoric $-\mathrm{N}=\mathrm{C}-\mathrm{O}-$ linkage in the $1,3,4-$ oxadiazole ring which isconsidered responsible for their potent biological activities. [17,18]. 1,3,4oxadiazole heterocyclics participate in hydrogen bonding interactions with different receptors because of their ester functionalities and very good bioisosteres of amide, thereby, shows a significant increase in biological activity [19].

Epilepsy is a diverse group of illnesses affecting over 60 million people worldwide. It is distinguished by episodes of hypersynchronous neuronal firing and hyper excitability accompanied by motor, sensory, or autonomic occurrences with or without loss of consciousness [20]. Many alternative treatments are available for treating epilepsy, such as neuromodulation, palliative surgery, and a ketogenic diet (KD). However, regardless of its efficacy, the unpalatable and antagonistic features of the ketogenic diet do not meet patient compliance, especially children [21].

Moreover, antiepileptic drug therapy terminates or minimizes seizure frequency in only up to $60-70 \%$ of patients, and long-term antiepileptic therapy (AEDs) remains the backbone of epilepsy treatment. Furthermore, $50 \%$ of epilepsy patients experience undesirable side effects of the available drug treatments, rendering therapy difficult, so there is a high demand for new anticonvulsants with minimal or no side effects [22,23]. 
GABA receptors are the principal mediators of fast synaptic inhibitory transmission in the human brain. A reduction in GABA receptor signalling activates hyperactive neurological disorders such as epilepsy, anxiety, and insomnia [24]. Inadequacy in GABA transmission has often been involved in epilepsy in animal models and human syndromes [25].

The 1,3,4-oxadiazole nucleus has garnered remarkable recognition for acting as a selective GABA potentiating potent anticonvulsant agent having both GABA and sodium channel mechanisms. It has also been reported that some of the derivatives containing 1,3,4-oxadiazole nucleus are better tolerated than benzodiazepines, making themmore desirable drugs for the treatment of epilepsy [26].

From the above observations, the therapeutic importance of the 1,3,4-oxadiazole ring appeared to be of great interest for its synthesis andfor developing possible modifications of the structural components in the general framework of oxadiazole with respect to their binding efficacy, potency, and selectivity which would guide in the design of new oxadiazole derivatives as anticonvulsants.

\section{Materials and methods}

The Equiptronics digital melting point apparatus was employed for determining the melting points, which were uncorrected. Thin-layer chromatography (TLC) was used to monitor the reaction progress using plates of Silica gel G. Spots of the TLC were visualized under a UV light chamber. ${ }^{1} \mathrm{H}-\mathrm{NMR}$ spectra were recorded using the Agilent-NMR 400-MR $\mathrm{DD}_{2}$ spectrometer operating at $400 \mathrm{MHz}$ using DMSO as a solvent. Chemical shift values are expressed in ppm $(\delta)$ values and TMS is used as an internal standard. An Alpha Bruker FT-IR Spectrometer was used for recording IR spectra $\left(\mathrm{cm}^{-1}\right)$ employing $\mathrm{KBr}$ disc. The Mass spectrum was recorded on the Waters LC-MS/MS instrument. All the chemical reagents as well as the required solvents were obtained from Sigma Aldrich, Bangalore, India.

\section{General procedure for the synthesis of 1,3,4-oxadiazole derivatives (C1-5)}

A mixture of p-hydroxybenzhydrazide (1) (0.01 mol) and substituted aromatic aldehydes (2) (0.01 mol) was taken in a round bottom flask and dissolved in dichloroformamide $(30 \mathrm{~mL})$. A pinch of ceric ammonium nitrate $(5 \mathrm{mg})$ was added and the contents were refluxed for $10-14 \mathrm{~h}$ and cooled to room temperature. The reaction contents were poured into crushed ice with constant stirring. The solid compound was filtered, washed with water, dried and recrystallized using alcohol. The physical data of title compounds is given in Table 1 [27].

Table 1 Physical data of 1,3,4oxadiazole derivatives (C1-5).

\begin{tabular}{cccc}
\hline Comp & Ar-CHO & Molecular formula & Molecular weight \\
\hline $\mathrm{C} 1$ & $4-\mathrm{Cl}$ & $\mathrm{C}_{14} \mathrm{H}_{9} \mathrm{Cl} \mathrm{N}_{2} \mathrm{O}_{2}$ & 272.69 \\
$\mathrm{C} 2$ & $2-\mathrm{NO}_{2}$ & $\mathrm{C}_{14} \mathrm{H}_{9} \mathrm{~N}_{3} \mathrm{O}_{4}$ & 283.24 \\
$\mathrm{C} 3$ & $4-\mathrm{Br}$ & $\mathrm{C}_{14} \mathrm{H}_{9} \mathrm{BrN}_{2} \mathrm{O}_{2}$ & 317.14 \\
$\mathrm{C} 4$ & $4-\mathrm{OCH}$ & $\mathrm{C}_{15} \mathrm{H}_{12} \mathrm{~N}_{2} \mathrm{O}_{3}$ & 268.27 \\
$\mathrm{C} 5$ & $3-\mathrm{OH}$ & $\mathrm{C}_{14} \mathrm{H}_{10} \mathrm{~N}_{2} \mathrm{O}_{3}$ & 254.24 \\
\hline
\end{tabular}

4-(5-(4-chlorophenyl)-1,3,4-oxadiazol-2-yl) phenol(C1)

White solid, \% yield: $81.09 \%$, m.p.: $258-260{ }^{\circ} \mathrm{C}$. FT-IR (KBr, v, cm $\left.{ }^{-1}\right): 3236(\mathrm{OH}), 2908(\mathrm{C}-\mathrm{H})$, $1624(\mathrm{C}=\mathrm{N}), 1554(\mathrm{C}=\mathrm{C}), 1082(\mathrm{C}-\mathrm{O}-\mathrm{C}), 747(\mathrm{C}-\mathrm{Cl}) .{ }^{1} \mathrm{H}-\mathrm{NMR}\left(\mathrm{DMSO}-\mathrm{d}_{6}, 400 \mathrm{MHz}\right) \delta \mathrm{ppm}=6.92-$ 8.65(m, Ar-H, 8H), 11.82 (s, OH, 1H). MS (m/z): $273.32(\mathrm{M}+1)$.

4-(5-(2-nitrophenyl)-1,3,4-oxadiazol-2-yl) phenol(C2)

Light yellow solid, \% yield: 78.04 \%, m.p.: 191-193 ${ }^{\circ} \mathrm{C}$. FT-IR (KBr, v, cm $\left.{ }^{-1}\right): 3205(\mathrm{OH})$, 1603(C=N), $1525(\mathrm{C}=\mathrm{C}), 2905(\mathrm{C}-\mathrm{H}), 1067(\mathrm{C}-\mathrm{O}-\mathrm{C}), 1482\left(\mathrm{NO}_{2}\right) .{ }^{1} \mathrm{H}-\mathrm{NMR}\left(\mathrm{DMSO}-\mathrm{d}_{6}, 400 \mathrm{MHz}\right) \delta$ ppm=6.92-8.84(m, Ar-H, 8H), $11.72(\mathrm{~s}, \mathrm{OH}, 1 \mathrm{H})$. MS (m/z): $284.28(\mathrm{M}+1)$. 
4-(5-(4-bromophenyl)-1,3,4-oxadiazol-2-yl) phenol (C3)

Dark brown solid, \% yield: $82.67 \%$, m.p.: 183-185 ${ }^{\circ} \mathrm{C}$. FT-IR $\left(\mathrm{KBr}, \mathrm{v}, \mathrm{cm}^{-1}\right): 3251(\mathrm{OH}), 1625$ $(\mathrm{C}=\mathrm{N}), 1554(\mathrm{C}=\mathrm{C}), 2931(\mathrm{C}-\mathrm{H}), 1072(\mathrm{C}-\mathrm{O}-\mathrm{C}), 750(\mathrm{C}-\mathrm{Br}) .{ }^{1} \mathrm{H}-\mathrm{NMR}\left(\mathrm{DMSO}-\mathrm{d}_{6}, 400 \mathrm{MHz}\right) \delta \mathrm{ppm}=6.91-$ 7.861(m, Ar-H, 8H), 11.86 (s, OH, 1H). MS (m/z): $317.14(\mathrm{M}+)$.

4-(5-(4-methoxyphenyl)-1,3,4-oxadiazol-2-yl) phenol (C4)

Brown solid, \% yield: $83.05 \%$, m.p.: $242-244{ }^{\circ} \mathrm{C}$. FT-IR $\left(\mathrm{KBr}, \mathrm{v}, \mathrm{cm}^{-1}\right): 3245(\mathrm{OH}), 1607(\mathrm{C}=\mathrm{N})$, $1555(\mathrm{C}=\mathrm{C}), 2905(\mathrm{C}-\mathrm{H}), 1098(\mathrm{C}-\mathrm{O}-\mathrm{C}) .{ }^{1} \mathrm{H}-\mathrm{NMR}\left(\mathrm{DMSO}_{6}, 400 \mathrm{MHz}\right) \delta \mathrm{ppm}=3.78\left(\mathrm{~s}, \mathrm{OCH}_{3}, 3 \mathrm{H}\right)$, 6.93-7.87 (m, Ar-H, 8H), 11.74 (s, OH, 1H). MS (m/z): 269.35(M+1).

\section{3-(5-(2-hydroxyphenyl)-1,3,4-oxadiazol-2-yl) phenol (C5)}

Light orange solid, \% yield: $76.56 \%$ m.p.: 214-216 ${ }^{\circ} \mathrm{C}$. FT-IR (KBr, v, $\left.\mathrm{cm}^{-1}\right): 3324(\mathrm{OH}), 1611$ $(\mathrm{C}=\mathrm{N}), 1551(\mathrm{C}=\mathrm{C}), 2926(\mathrm{C}-\mathrm{H}), 1097(\mathrm{C}-\mathrm{O}-\mathrm{C}) .{ }^{1} \mathrm{H}-\mathrm{NMR}\left(\mathrm{DMSO}_{6}, 400 \mathrm{MHz}\right) \delta \mathrm{ppm}=6.92-8.02(\mathrm{~m}, \mathrm{Ar}-$ $\mathrm{H}, 8 \mathrm{H}), 11.77$ (s, OH, 1H), $12.06(\mathrm{~s}, \mathrm{OH}, 1 \mathrm{H}) . \mathrm{MS}(\mathrm{m} / \mathrm{z}): 255.30(\mathrm{M}+1)$.

\section{In silico analysis}

In silico analysis (Lipinski's RO5, molecular docking, ADME properties was carried out using Schrodinger 2018-3 suite device Maestro 11.7.012, (Ligprep, Glide XP docking, QuikProp). The synthesized compounds were docked in the groove of the binding site in 4COF, which is the crystal structure of a human gamma-amino butyric acid receptor, the GABA(A)R-beta3 homopentamerwith a resolution of $2.97^{\circ} \mathrm{A}$ which is the major inhibitory neurotransmitter in the human brain $[28,29]$.

\section{Anticonvulsant activity}

Animals

Swiss albino mice (weighing 20 - $25 \mathrm{~g}$ ) of either sex were used for the study. The animals were obtained a week before experimentation from the animal house facility of Nitte-Deemed to be University, Mangalore, Karnataka, and kept in the lab for acclimatization. They were housed and maintained under $12 \mathrm{~h}$ dark/light cycles at $27 \pm 2{ }^{\circ} \mathrm{C}$ in polypropylene cages. They were fed with water and standard pellet feed except during the experiments. Pregnant females were excluded. Ethical clearance for experimentation on animals was taken from the IAEC (Certificate No: NGSMIPS/IAEC/120) prior to the start of the work.

\section{Acute toxicity studies}

Standard husbandry conditions were maintained for the acute toxicity studies of 1,3,4-oxadiazole derivatives $(\mathrm{OECD}, 2001)$ on female albino mice $(20-25 \mathrm{~g})$. Prior to the experimentation, the animals were fasted over-night and were treated with a single dose of 1,3,4-oxadiazole derivatives and monitored for a period of $48 \mathrm{~h}$ for mortality (short term toxicity). Based on the short-term toxicity profile, the next doses were determined according to the OECD guidelines No.425 [30].

\section{Maximal electroshock method}

Swiss albino mice of either sex with a bodyweight of $20-25 \mathrm{~g}$ were divided into 6 groups of 6 animals each. Group-I was given a1\% aqueous solution of tween 80 as a control, while Group-II was administered phenytoin ( $25 \mathrm{mg} / \mathrm{kg}$ p.o) and served as a standard. Groups-III-VII were orally administered with respective 1,3,4-oxadiazole derivatives at a dose of $100 \mathrm{mg} / \mathrm{kg}$, respectively. The experiment was started $45 \mathrm{~min}$ after the administration of vehicle or the test compounds and $30 \mathrm{~min}$ after the standard drug. To start the session, a $60 \mathrm{~Hz}$ alternate current for $0.2 \mathrm{~s}$ was applied to the animal through corneal electrodes. The different stages of convulsion flexion, hind limb extension, stupor, the total duration of the convulsion, and the recovery period taken were recorded (Table 7 and Figure 5). The decrease in duration of the hind limb extension is considered as a protective action that implies anticonvulsant activity [31].

\section{PTZ induced convulsions}

Swiss albino mice of either sex with a bodyweight of $20-25$ g were divided into 6 groups of 6 animals each. Group-I was given a1\% aqueous solution of tween 80 served as a control, Group-II served as standard which was administered with diazepam $(5 \mathrm{mg} / \mathrm{kg}$ i.p). Groups III-VII were given 1,3,4oxadiazole derivatives orally at a dose of $100 \mathrm{mg} / \mathrm{kg}$, respectively. After $45 \mathrm{~min}$ of the vehicle or test compounds and $30 \mathrm{~min}$ after the standard drug, the PTZ $(80 \mathrm{mg} / \mathrm{kg}$ weight s.c.) was given to the mice. 
Immediately after PTZ administration, the mice were placed individually in a cage and observed for latency to clonic convulsions and mortality for the duration of $30 \mathrm{~min}$ (Table 8 and Figure 6) [32].

\section{Statistical analysis}

The results are presented as Mean $\pm \mathrm{SEM}, \mathrm{n}=6$. One-way ANOVA was used for a statistical demonstration followed by Dunnett's multiple comparison test, and $p<0.05$ value was considered significant.

\section{Results and discussion}

Chemistry

1,3,4-oxadiazole derivatives were prepared in a satisfactory yield by refluxing 4-hydroxy benzhydrazide with various substituted aromatic aldehydes and adding a pinch of ceric ammonium nitrate which acts as a catalyst and dimethylformamide was used as solvent. All the title compounds were obtained in good yield. The reaction sequence followed is outlined in Scheme-01. The physical data of the final synthesized compounds were shown in Table 1. Based on FT-IR, ${ }^{1} \mathrm{H}-\mathrm{NMR}$ and Mass spectral data, all the new compounds were confirmed to have their assigned structure.

\section{Scheme-01}<smiles>NC(=O)c1ccc(O)cc1</smiles>

(1)<smiles>O=Cc1cccc(Br)c1</smiles>

(2)<smiles>Oc1ccc(-c2nnc(-c3ccc(Br)cc3)o2)cc1</smiles>

Scheme 1

\section{In silico analysis}

The compounds showed desired physicochemical properties with no violations ofthe standard ranges (Table 2). The number of rotatable bonds is less than 10 for all compounds. The tPSA values of all the compounds are within the limit indicating the cell permeability. The synthesized compounds obey Lipinski's rule of 5 (Table 3). 
Table 2 Physicochemical properties of compounds (C1-C5).

\begin{tabular}{|c|c|c|c|c|c|}
\hline Comp & $\mathrm{MR}^{\mathrm{a}}\left(\mathrm{cm}^{3} / \mathrm{mol}\right)$ & $\mathbf{t P S A}^{\mathbf{b}}$ & Polarizability (§3) & Nrobs $^{c}$ & Volume $\left(\mathrm{cm}^{3}\right)$ \\
\hline $\mathrm{C} 1$ & $70.7 \pm 69$ & 54.18 & $28.0 \pm 0.510^{-24}$ & 2 & 221.67 \\
\hline $\mathrm{C} 2$ & $72.34 \pm 0.3$ & 104.98 & $28.68 \pm 0.510^{-24}$ & 3 & 231.47 \\
\hline C3 & $73.49 \pm 0.3$ & 59.15 & $29.13 \pm 0.510^{-24}$ & 2 & 226.02 \\
\hline $\mathrm{C} 4$ & $72.47 \pm 0.3$ & 68.39 & $28.73 \pm 0.510^{-24}$ & 3 & 233.68 \\
\hline $\mathrm{C} 5$ & $67.68 \pm 0.3$ & 79.38 & $26.83 \pm 0.510^{-24}$ & 2 & 216.15 \\
\hline $\begin{array}{c}\text { Standard } \\
\text { (Diazepam) }\end{array}$ & $80.91 \pm 0.5$ & 32.47 & $32.07 \pm 0.510^{-24}$ & 1 & 216.54 \\
\hline
\end{tabular}

amolar refractivity

$\mathrm{b}_{\text {total }}$ polar surface area

c number of rotatable bonds

Table 3 Lipinski’s RO5 for compounds (C1-5).

\begin{tabular}{ccccc}
\hline Comp & Molecular weight & Log P & DonorHB & AcceptorHB \\
\hline C1 & 272.69 & 3.44 & 1 & 3.250 \\
C2 & 283.24 & 3.16 & 1 & 4.250 \\
C3 & 317.14 & 3.71 & 1 & 3.250 \\
C4 & 268.27 & 2.75 & 1 & 4.000 \\
C5 & 254.24 & 2.49 & 2 & 4.000 \\
Standard & 284.75 & 2.84 & 0 & 4.000 \\
(Diazepam) & & & 0 \\
\hline
\end{tabular}

The new compounds were docked in the groove of the binding site in 4COF. Table 4 shows the affinity of the compounds for the receptor as well as their docking score. The synthesized compounds have binding free energy in the range of -4.977 to $5.676 \mathrm{kcal} / \mathrm{mol}$. The active residues in $4 \mathrm{COF}$ are ARG C:117, GLY D:158, TYR D:157, SER D:156, GLU D:155, ARG D:207, TYR D:97, LEU D:99, TYR D: 205, LEU D:99, TYR C:62, ASN C:41, GLN C:64, ASP C:43, THR D:202, ALA D:201, PHE D:200, THR C:176, GLY C:177, ARG C:180, MET C:115. The highest affinity as well as the binding energy of $-5.676 \mathrm{kcal} / \mathrm{mol}$ is displayed by Compound $\mathrm{C} 5$ in comparison to the other synthesized compounds. Compounds $\mathrm{C} 5, \mathrm{C} 4$ and $\mathrm{C} 1$ fit into the binding cleft of 4COF receptor with dock score of $-5.676,-5.277$ and $-5.191 \mathrm{kcal} / \mathrm{mol}$ respectively. The hydrogen bond interactions are formed with GLU D:155 in the case of both C5 (Figure 1) and C4 (Figure 2). The hydrophobic interaction between the ligand and the receptor also represents good interaction. The docking conformations of these 2 compounds are represented in Figures 3 and 4. 
Table 4 Dock scores of compounds (C1-C5) at the active site of 4COF.

\begin{tabular}{cc}
\hline Comp & Dock score \\
\hline Std (Diazepam) & $-\mathbf{4 . 5 5 4}$ \\
C1 & $-5.191^{*}$ \\
C2 & -5.039 \\
C3 & -5.149 \\
C4 & $-5.277^{* *}$ \\
C5 & $-\mathbf{5 . 6 7 6}^{* * *}$ \\
\hline
\end{tabular}

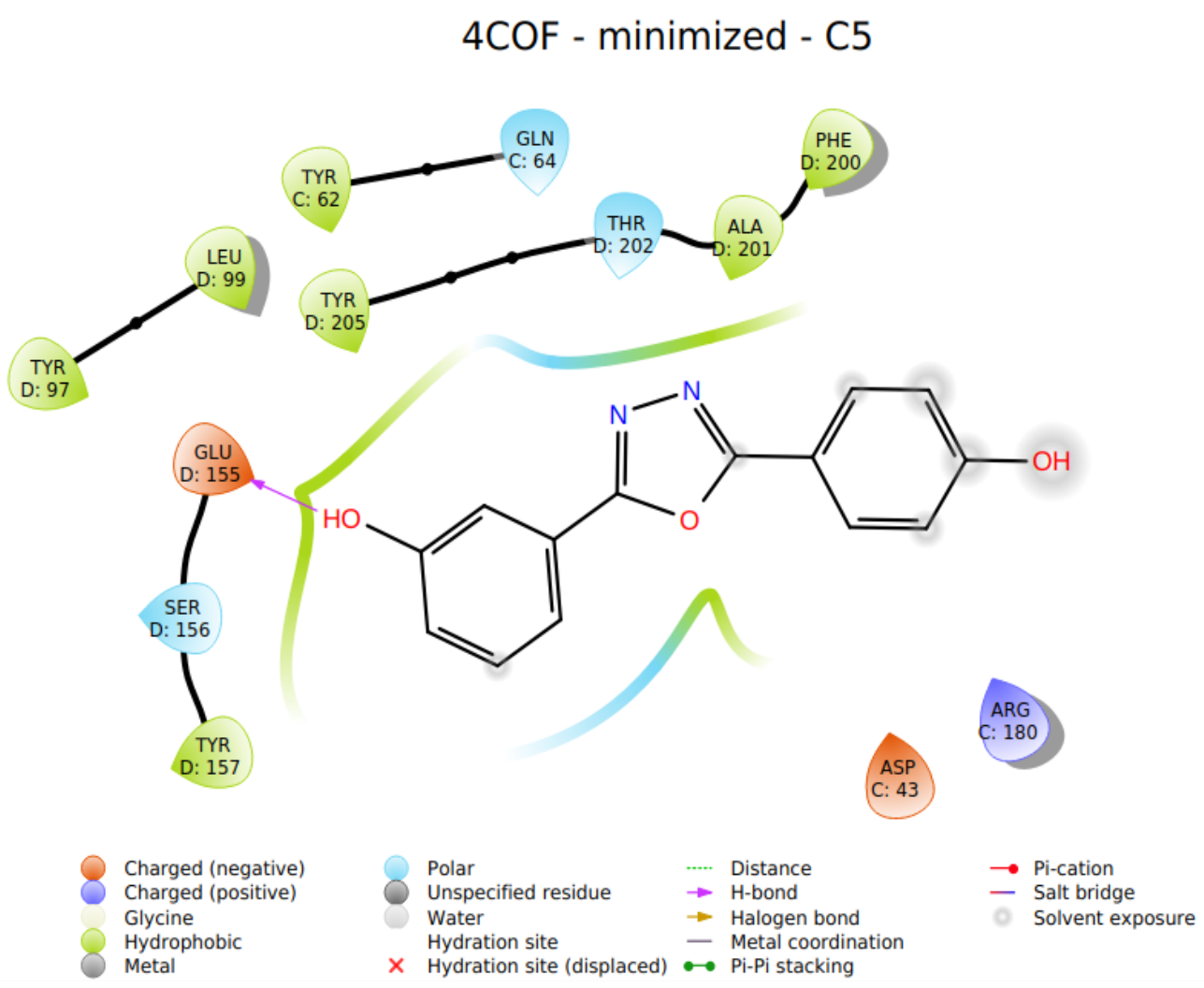

Figure 1 Interaction of compound $\mathrm{C} 5$ with $4 \mathrm{COF}$. 


\section{COF - minimized - C4}
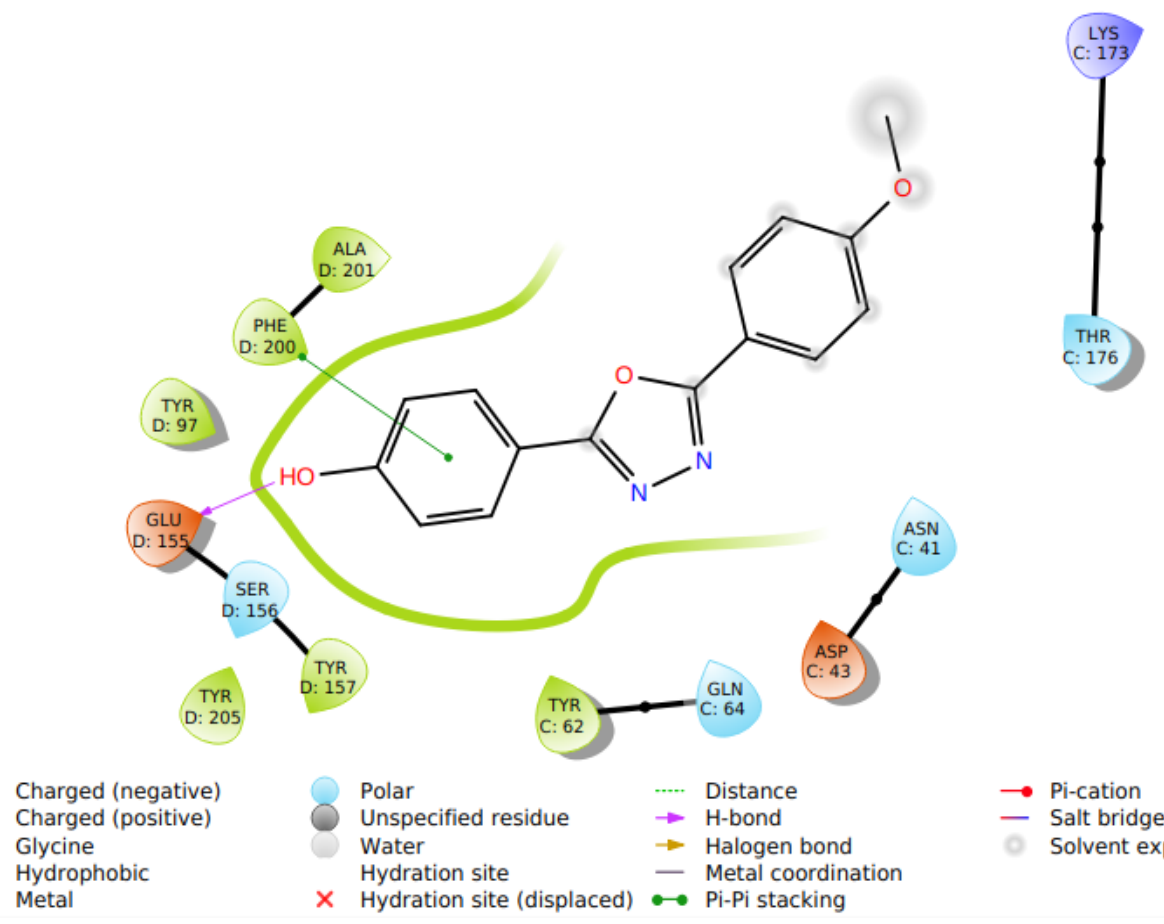

Figure 2Interactions of compound $\mathrm{C} 4$ with $4 \mathrm{COF}$.

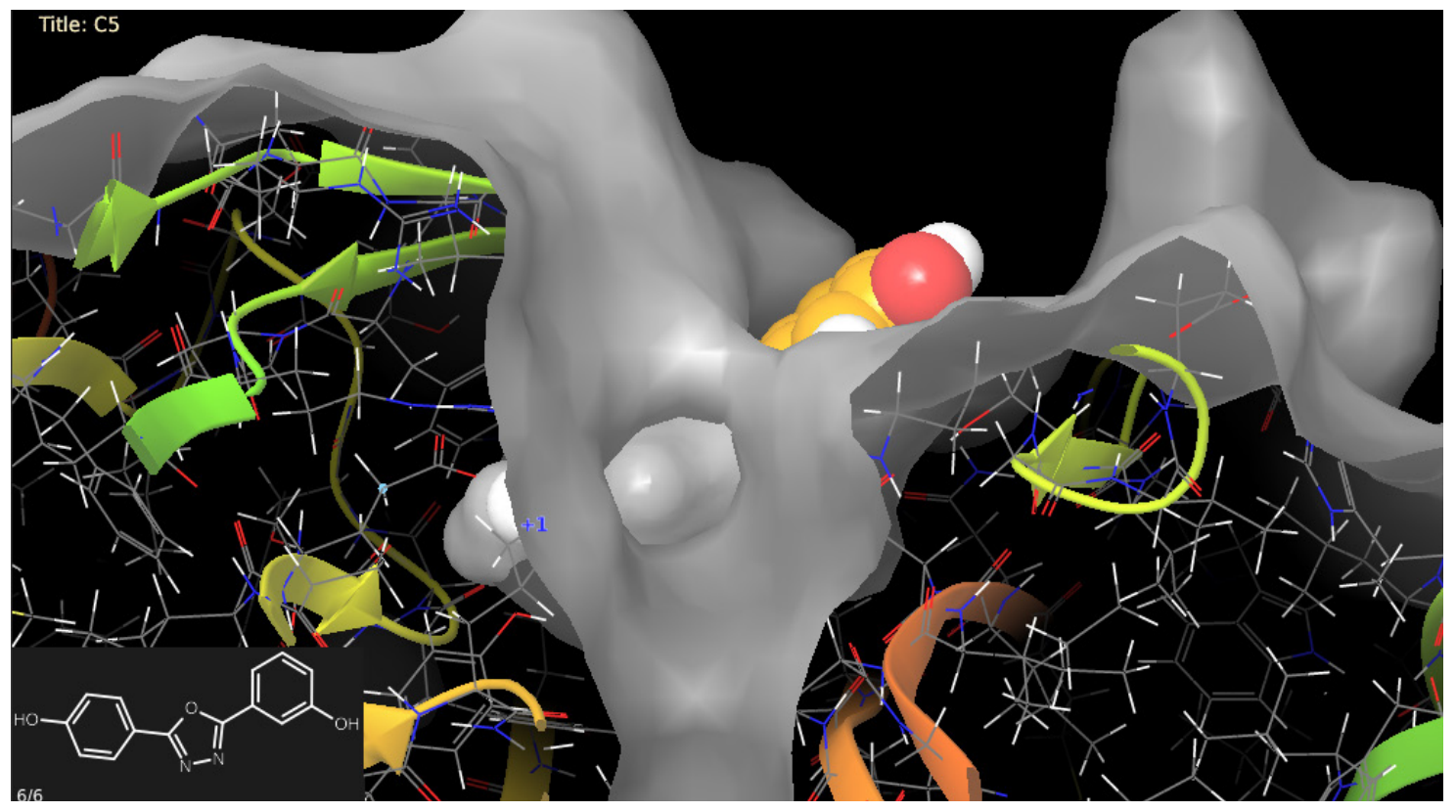

Figure 3 Docking interaction of C5 with $4 \mathrm{COF}$. 


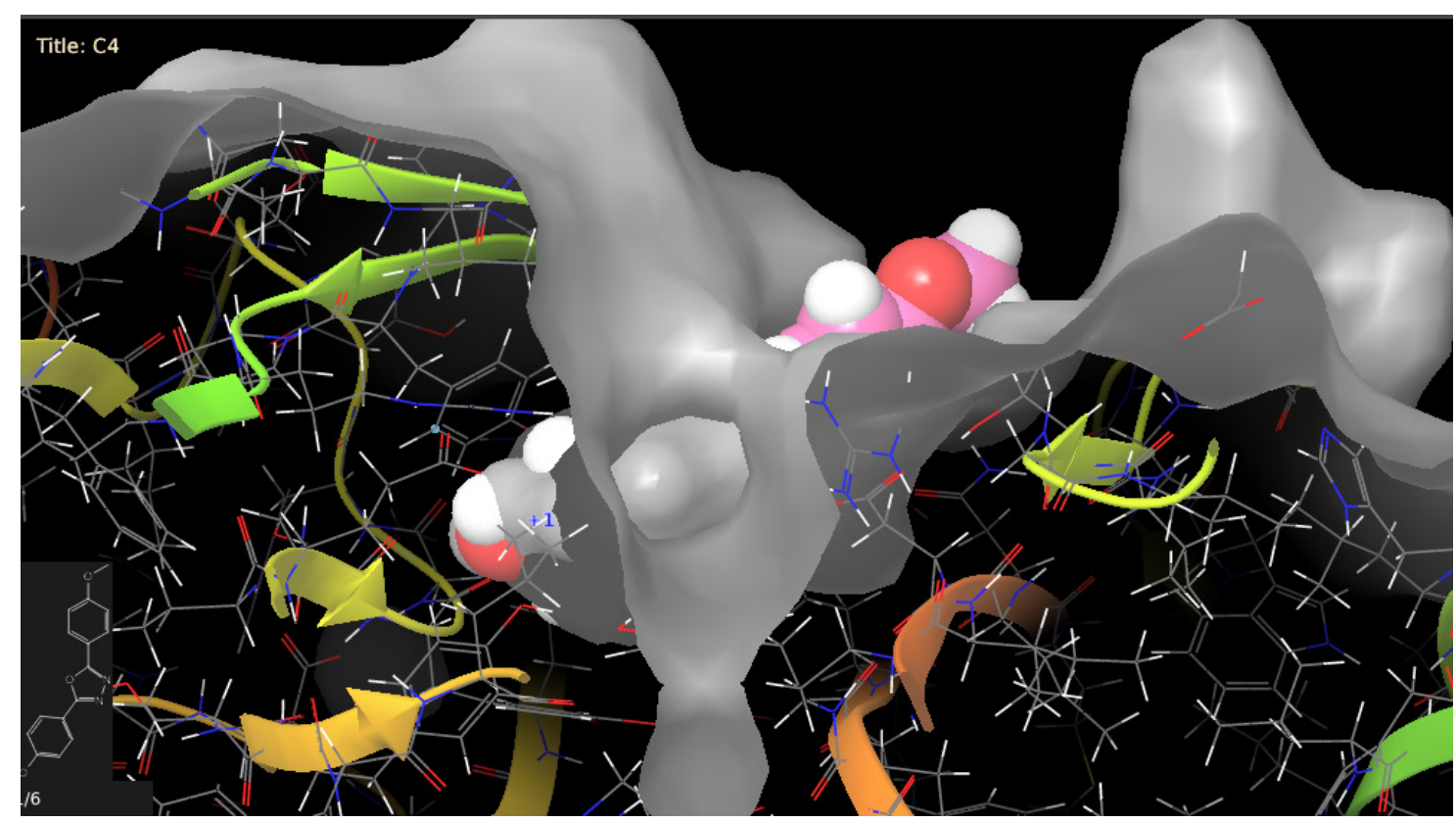

Figure 4 Docking interaction of $\mathrm{C} 4$ with $4 \mathrm{COF}$.

The co-crystallized ligand was removed from the prepared protein (PDB: 4COF) and redocked at the binding site to validate the docking program. To compare the docked and reference conformations, the RMSD value is employed. When relocking or cross-docking is done, the RMSD number will be lower (ideally less than $1 \AA$ ). The RMSD is primarily utilised to validate the docking study method. RMSD was calculated in molecular docking to compare the docked conformation of the reference ligand to its original conformation and to validate the protein-bound ligand docked in the same pocket to check the deviation. For the prepared PDB: 4COF, the RMSD values were found to be $0.098 \AA$. The values found had the least RMSD value and were chosen for continued study. At the ligand-binding site, all of the produced ligands were docked with the protein. The XP docking dock score data were analyzed and summarised.

The ADME studies (Table 5) of the synthesized compounds helped in concluding that all the compounds have good BBB penetration as that of the standard shown in Table 5. The QPlogKp score indicates that all the test compounds and the standard have skin permeability. The QPlogKhsa score depicted that all the compounds were bound to the human serum albumin.

Table 5 ADME properties of compounds (C1-5).

\begin{tabular}{cccccc}
\hline Comp & QPlogBB $^{\mathbf{a}}$ & QPlogKp $^{\mathbf{b}}$ & QPPCaco $^{\mathbf{c}}$ & QPlogKhsa $^{\mathbf{d}}$ & Percent human oral absorption $^{\text {QP1 }}$ \\
\hline C.291 & -2.196 & 998.094 & 0.244 & 100.00 \\
C2 & -1.443 & -3.931 & 119.539 & 0.093 & 75.50 \\
C3 & -0.280 & -2.199 & 998.179 & 0.270 & 100.00 \\
C4 & -0.528 & -2.130 & 997.311 & 0.149 & 96.88 \\
C5 & -1.009 & -3.087 & 303.303 & -0.026 & 82.91 \\
Standard & 0.200 & -1.669 & 2687.20 & 0.152 & 100.00 \\
(Diazepam) & & &
\end{tabular}

${ }^{\mathrm{a}}$ Predicted brain/blood partition coefficient.

${ }^{\mathrm{b}}$ Predicted skin permeability

${ }^{\mathrm{c}}$ Predicted apparent Caco- 2 cell permeability in $\mathrm{nm} / \mathrm{s}$.

${ }^{\mathrm{d}}$ Prediction of binding to human serum albumin. 
The Lazar program was used to predict the toxicity of the synthesized compounds (Table 6). The compounds of $\mathrm{C} 2$ were liable to cause mutagenicity. Whereas compounds $\mathrm{C} 3$ were liable to cause carcinogenicity, the remaining synthesized compounds were not found to be liable to cause any type of mutagenicity or carcinogenicity. All the synthesized compounds were not susceptible to causingacute toxicity and hence can be termed as safe.

Table 6 In silico toxicity prediction of compounds (C1-5).

\begin{tabular}{ccccc}
\hline & \multicolumn{4}{c}{ Toxicity prediction using LAZAR } \\
\cline { 2 - 5 } Comp & $\begin{array}{c}\text { Maximum recommended } \\
\text { daily dose } \\
\text { (mmol/kg-bw/day) }\end{array}$ & Mutagenicity & $\begin{array}{c}\text { Acute toxicity LC50 } \\
\text { (mmol/L) (Fathead } \\
\text { Minnow) }\end{array}$ & $\begin{array}{c}\text { Carcinogenic } \\
\text { potency }\end{array}$ \\
\hline Std & 0.00757 & - & 0.15 & - \\
(Diazepam) & 0.0825 & - & 0.0371 & - \\
C1 & 0.00347 & + & 0.322 & - \\
C2 & - & - & 0.00646 & - \\
C3 & 0.0902 & - & 0.886 & - \\
C4 & 0.00347 & - & 0.347 & - \\
C5 & & & & - \\
\hline
\end{tabular}

\section{Anticonvulsant activity}

All the newly synthesized compounds were screened for anticonvulsant activity by 2 models; namely, MES and PTZ induced convulsions (Tables 7 and 8). In both models, latency and duration are essential parameters to assess the anticonvulsant property. Compounds C4 [4-(5-(4-methoxyphenyl)1,3,4-oxadiazol-2-yl) phenol] and C5 [3-(5-(4-hydroxyphenyl)-1,3,4-oxadiazol-2-yl) phenol] have shown a decrease in the flexion phase as well as in the extension phase. Also, compound $\mathbf{C 5}$ has demonstrated a decline in the clonus phase, and compound $\mathbf{C 4}$ has shown a decrease in the stupor phase. Overall, compounds $\mathbf{C 4}$ and $\mathbf{C 5}$ show convulsion duration times closer to thoseof standard drugs.

In the PTZ induced convulsion model, compounds $\mathbf{C 5}$ and $\mathbf{C 3}$ have shown the highest increasesin the latency phase, as well as compounds $\mathbf{C 5}$ and $\mathbf{C 1}$ showed a significant decrease in the duration time of the tonic-clonic seizure when compared to that of the control.

Remarkably, the presence of both electron-donating and withdrawing groups substituted at the 2and 5-position of the 1,3,4-oxadiazole ring resulted in excellent anticonvulsant activity. Compound C4 with paramethoxy substituent illustrates the distal hydrophobic centre could be made to be more lipophilic than the phenyl ring, thus demonstrating more significant anticonvulsant potential.

Table 7 Data of anticonvulsant activity study by MES method.

\begin{tabular}{ccccccc}
\hline $\begin{array}{c}\text { Sl. } \\
\text { No }\end{array}$ & Treatment & Dose & $\begin{array}{c}\text { Duration of } \\
\text { flexion phase }\end{array}$ & $\begin{array}{c}\text { Duration of } \\
\text { extension phase }\end{array}$ & $\begin{array}{c}\text { Duration of } \\
\text { clonus phase }\end{array}$ & $\begin{array}{c}\text { Duration of } \\
\text { stupor phase }\end{array}$ \\
\hline 1 & $\begin{array}{c}\text { Control } \\
\text { Standard }\end{array}$ & - & $1.880 \pm 0.058$ & $24.40 \pm 1.66$ & $38.0 \pm 3.85$ & $84.20 \pm 4.375$ \\
2 & $25 \mathrm{mg} / \mathrm{kg}$ (p.o) & $0.52 \pm 0.049$ & $8.400 \pm 5.40$ & $3.40 \pm 0.51$ & $9.40 \pm 1.939$ \\
& (Phenytoin) & & & & \\
3 & $\mathrm{C} 1$ & $100 \mathrm{mg} / \mathrm{kg}$ (p.o) & $2.20 \pm 0.200$ & $14.00 \pm 2.366$ & $34.40 \pm 4.905$ & $44.60 \pm 19.35^{* *}$ \\
4 & $\mathrm{C} 2$ & $100 \mathrm{mg} / \mathrm{kg}$ (p.o) & $3.60 \pm 0.678$ & $15.200 \pm 2.22$ & $31.40 \pm 4.966$ & $66.80 \pm 24.105$ \\
5 & $\mathrm{C} 3$ & $100 \mathrm{mg} / \mathrm{kg}$ (p.o) & $2.20 \pm 0.200$ & $12.800 \pm 1.66$ & $51.80 \pm 9.499$ & $42.00 \pm 4.764^{* *}$ \\
6 & $\mathrm{C} 4$ & $100 \mathrm{mg} / \mathrm{kg}$ (p.o) & $1.80 \pm 0.490$ & $7.400 \pm 2.015$ & $17.80 \pm 7.567$ & $14.20 \pm 6.453^{* * * *}$ \\
7 & $\mathrm{C} 5$ & $100 \mathrm{mg} / \mathrm{kg}$ (p.o) & $1.00 \pm 0.316$ & $11.00 \pm 2.97$ & $15.200 \pm 4.03$ & $20.60 \pm 9.453^{* * * *}$ \\
\hline
\end{tabular}

The above data is presented as mean \pm SEM, $n=6$. 
Table 8 Data of anticonvulsant activity study by PTZ induced convulsion method.

\begin{tabular}{ccccc}
\hline Sl. No & Treatment & Dose & $\begin{array}{c}\text { Latency of tonic } \\
\text { clonic seizures (s) }\end{array}$ & Duration of tonic clonic seizure (s) \\
\hline 1 & Control & - & $22.59 \pm 0.33$ & $288.8 \pm 3.77$ \\
2 & Standard & $5.0 \mathrm{mg} / \mathrm{kg}$ (p.o) & $287.6 \pm 4.61$ & $67.40 \pm 3.076$ \\
3 & $\mathrm{C} 1$ & $100 \mathrm{mg} / \mathrm{kg}(\mathrm{p} . \mathrm{o})$ & $57.60 \pm 10.70$ & $184.6 \pm 56.55$ \\
4 & $\mathrm{C} 2$ & $100 \mathrm{mg} / \mathrm{kg}(\mathrm{p} . \mathrm{o})$ & $44.00 \pm 4.743$ & $285.2 \pm 27.18$ \\
5 & $\mathrm{C} 3$ & $100 \mathrm{mg} / \mathrm{kg}(\mathrm{p} .0)$ & $74.40 \pm 15.70^{*}$ & $317.0 \pm 18.13$ \\
6 & $\mathrm{C} 4$ & $100 \mathrm{mg} / \mathrm{kg}(\mathrm{p} .0)$ & $61.60 \pm 20.77$ & $217.0 \pm 59.07$ \\
7 & $\mathrm{C} 5$ & $100 \mathrm{mg} / \mathrm{kg}(\mathrm{p} .0)$ & $81.00 \pm 20.22^{*}$ & $123.8 \pm 6.62^{*}$ \\
\hline
\end{tabular}

The above data is presented as mean $\pm \operatorname{SEM}, \mathrm{n}=6$.

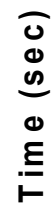
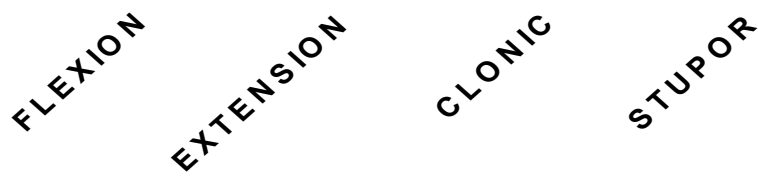

Figure 5 Duration of various phases of convulsion by MES induced convulsion. 


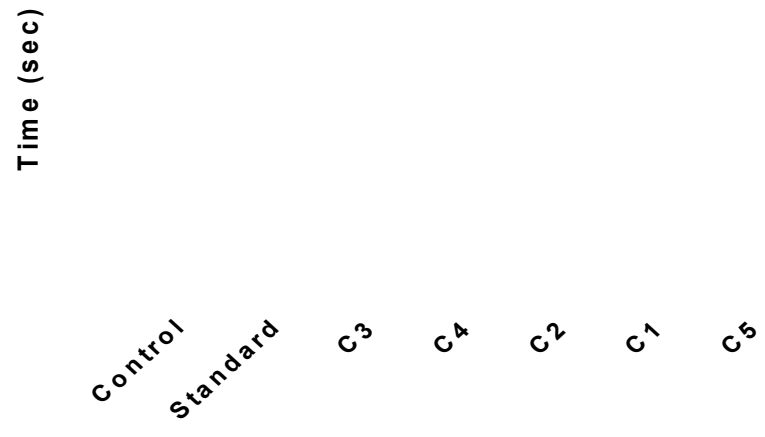

Figure 6 Latency of convulsion in PTZ induced convulsion.

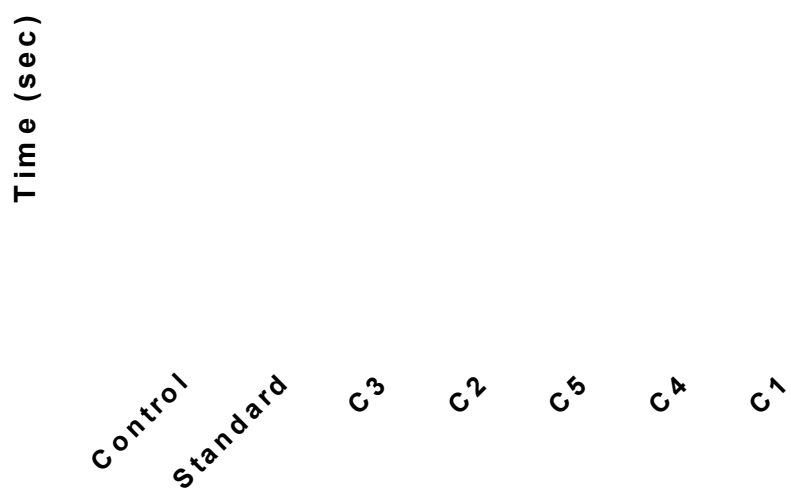

Figure 7 Duration of convulsion in PTZ induced convulsion.

\section{Conclusions}

In summary, a new series of 1,3,4-oxadiazole derivatives were conveniently synthesized from 4hydroxy benzhydrazide and substituted aromatic aldehydes with good yields. Molecular docking studies represent a significant interaction between the ligand and the GABAA receptor. The in silico predictions resulted in supportive pharmacokinetic potency, and the Lazy structure-activity relationship (LAZAR) framework used for toxicity predictions revealed that the majority of the synthesized compounds were carcinogenic and mutagenic. Compounds C4 and C5 showed the highest affinity and binding energy, as well as the highest anticonvulsant activity in both electroshock and pentylenetetrazole-induced lethal convulsion tests. The results manifest that the compounds with the highest activity can be further used as a framework for design, alteration, and exploration to construct more effective analogs with lesser side effects. 


\section{Acknowledgment}

The authors would like to thank Nitte CADD Lab, Nitte- Deemed to be University, Mangalore, India, for providing all the necessary facilities for carrying out this work and University of Mysore, Institute of Excellence, Mysore, Karnataka for recording NMR and Mass spectral data.

\section{References}

[1] S Bala, S Kamboj and A Kumar. Heterocyclic 1,3,4-oxadiazole compounds with diverse biological activities: A comprehensive review. J. Pharm. Res. 2010; 3, 2993-7.

[2] E Palaska, G Şahin, P Kelicen, NT Durlu and G Altinok. Synthesis and anti-inflammatory activity of 1-acylthiosemicarbazides, 1,3,4-oxadiazoles, 1,3,4-thiadiazoles and 1,2,4-triazole-3-thiones. IL Farmaco 2002; 57, 101-7.

[3] AMME Omar and OM Aboulwafa. Synthesis and anticonvulsant properties of a novel series of 2-substituted amino-5-aryl-1, 3, 4-oxadiazole derivatives. J. Hetero. Chem. 1984; 21, 1415-28.

[4] G Şahin, EPalaska, M Ekizoğlu and M Özalp. Synthesis and antimicrobial activity of some 1,3,4oxadiazole derivatives. IL Farmaco 2002; 57,539-42.

[5] SV Bhandari, KG Bothara, MK Raut, AA Patil, AP Sarkate and VJ Mokale. Design, synthesis and evaluation of antiinflammatory, analgesic and ulcerogenicity studies of novel S-substituted phenacyl-1,3,4-oxadiazole-2-thiol and Schiff bases of diclofenac acid as nonulcerogenic derivatives. Bio. Med. Chem. 2008; 16, 1822-31.

[6] HP Shah, B Shah, JJ Bhatt, NC Desai, PB Trivedi and NK Undavia. Synthesis of 2,5-disubstituted 1,3,4-oxadiazoles as potential antimicrobial, anticancer and anti-HIV agents. ChemInform 1998; 29, 199839132.

[7] AO Maslat, M Abussaud, H Tashtoush and M AL-Talib. Synthesis, antibacterial, antifungal and genotoxic activity of bis-1,3,4-oxadiazole derivatives. Pol. J. Pharmacol. 2002; 54, 55-9.

[8] AS Aboraia, HM Abdel-Rahman, NM Mahfouz and MA El-Gendy. Novel 5-(2-hydroxyphenyl)-3substituted-2, 3-dihydro-1, 3, 4-oxadiazole-2-thione derivatives: Promising anticancer agents. Bio. Med. Chem. 2006; 14, 1236-46.

[9] AA Santilli and RL Morris. Synthesis of 3-arylsulfonylmethyl-1,2,4-oxadiazole-5-carboxylic acid derivatives. J. Hetero. Chem. 1979; 16, 1197-200.

[10] J Roh, GKarabanovich, H Vlčková, A Carazo, J Němeček, P Sychra, L Valášková, O Pavliš, J Stolaříková, V Klimešová and K Vávrová. Development of water-soluble 3,5-dinitrophenyl tetrazole and oxadiazoleantitubercular agents. Bio. Med. Chem. 2017; 5, 5468-76.

[11] D Dewangan, A Pandey, T Sivakumar, R Rajavel and RD Dubey. Synthesis of some novel 2,5disubstituted 1,3,4-oxadiazole and its analgesic, anti-inflammatory, anti-bacterial and anti-tubercular activity. Int. J. Chem. Tech. Res. 2010; 2, 1397-412.

[12] SU Haque, H Welch, M Dashwood, B Ramesh and M Loizidou. Efficacy of zibotentan in colorectal cancer-response. Mol. Cancer Thera. 2014; 13, 674-80.

[13] NB Patel, JN Patel, AC Purohit, VM Patel, DP Rajani, R Moo-Puc, JC Lopez-Cedillo, B NoguedaTorres and G Rivera. In vitro and in vivoassessment of newer quinoxaline-oxadiazole hybrids as antimicrobial and antiprotozoal agents. Int. J. Antimicrob. Agents 2017; 50, 413-8.

[14] V Summa, A Petrocchi, F Bonelli, B Crescenzi, M Donghi, M Ferrara, F Fiore, C Gardelli, OG Paz, DJ Hazuda, P Jones, O Kinzel, R Laufer, E Monteagudo, E Muraglia, E Nizi, F Orvieto, P Pace, G Pescatore, R Scarpelli, K Stillmock, MV Witmer and M Rowley. Discovery of raltegravir, a potent, selective orally bioavailable HIV-integrase inhibitor for the treatment of HIV-AIDS infection. $J$. Med. Chem. 2008; 51, 5843-55.

[15] NC Desai, N Bhatt, H Somani and A Trivedi. Synthesis, antimicrobial and cytotoxic activities of some novel thiazole clubbed 1,3,4-oxadiazoles. Eur. J. Med. Chem. 2013; 67, 54-9.

[16] ML Cohen, KS Wiley and AS Landry. In vitro comparison of the pre-and postsynaptic alpha adrenergic receptor blocking properties of prazosin and tiodazosin (BL5111). Clin. Exp. Hypertens. 1980; 2, 1067-82.

[17] NC Desai, GMKotadiya, ARTrivedi, VMKhedkar and PCJha. Design, synthesis, and biological evaluation of novel fluorinated pyrazole encompassing pyridyl 1,3,4-oxadiazole motifs. Med. Chem. Res. 2016; 25, 2698-717.

[18] PP Roy, S Bajaj, TK Maity and J Singh. Synthesis and evaluation of anticancer activity of 1,3,4oxadiazole derivatives against ehrlich ascites carcinoma bearing mice and their correlation with histopathology of liver. receptor. Ind. J. Pharm. Edu. Res. 2017; 51, 260-69. 
[19] A Rigo and M Lagrenee. A simple and efficient procedure for synthesis of optically active 1,3,4oxadiazole derivatives containing Lamino acid moieties. J. Het. Chem. 1999; 36, 1029-32.

[20] R Kumar, T Singh, H Singh, S Jain and RK Roy. Design, synthesis and anticonvulsant activity of some new 6, 8-halo-substituted-2h-[1,2,4] triazino [5,6-b] indole-3 (5h)-one/-thione and 6, 8-halosubstituted 5-methyl-2h-[1,2,4] triazino [5,6-b] indol-3 (5h)-one/-thione. Exp. Clin. Sci. J. 2014; 13, 225-32.

[21] I D’AndreaMeira, TTRomão, HJPD Prado, LTKrüger, MEPPires and PODConceição. Ketogenic diet and epilepsy: What we know so far. Front. Neurosci.2019;13, 5.

[22] MM Goldenberg. Overview of drugs used for epilepsy and seizures: Etiology, diagnosis, and treatment. Pharm. Thera. 2010; 35, 392-400.

[23] HA Abuelizz, RE Dib, M Marzouk, EH Anouar, YA Maklad, HN Attia and R Al-Salahi. Molecular docking and anticonvulsant activity of newly synthesized quinazoline derivatives. Molecules 2017; 22, 1094-80.

[24] PS Miller and AR Aricescu. Crystal structure of a human GABA receptor. Nature 2014; 512, 2705.

[25] TM DeLorey and RW Olsen. GABA and epileptogenesis: Comparing gabrb3 gene-deficient mice with Angelman syndrome in man. Epilepsy Res. 1999; 36, 123-32.

[26] HJ Lankau, K Unverferth, C Grunwald, H Hartenhauer, K Heinecke, K Bernöster, R Dost, U Egerland and C Rundfeldt. New GABA-modulating 1,2,4-oxadiazole derivatives and their anticonvulsant activity. Euro. J. Med. Chem. 2007; 42, 873-9.

[27] BF Gatphoh, BC Revanasiddappa, MV Kumar and H Kumar. Synthesis, anti-arthritic and antioxidant activities of novel 1,3,4-oxadiazole derivatives. Synthesis, anti-arthritic and antioxidant activities of novel 1,3,4-oxadiazole derivatives. Indian Drugs 2018; 55, 18-23.

[28] M Tanaka, RW Olsen, MT Medina, E Schwartz, ME Alonso, RM Duron, R Castro-Ortega, IE Martinez-Juarez, IPascual-Castroviejo, J Machado-Salas, R Silva, JN Bailey, D Bai, A Ochoa, A Jara-Prado, G Pineda, RL Macdonald and AV Delgado-Escueta. Hyperglycosylation and reduced GABA currents of mutated GABRB3 polypeptide in remitting childhood absence epilepsy. Am. J. Hum. Genet. 2008; 82, 1249-61.

[29] KN Gurba, CC Hernandez, N Hu and RL Macdonald. GABRB3 mutation, G32R, associated with childhood absence epilepsy alters $\alpha 1 \beta 3 \gamma 2 \mathrm{~L} \gamma$-aminobutyric acid type A $\left(\mathrm{GABA}_{\mathrm{A}}\right)$ receptor expression and channel gating. J. Bio. Chem. 2012; 287, 12083-97.

[30] DO Chemicals. OECD Guideline for testing of chemicals. The Organisation for Economic Cooperation and Development, Paris, France, 2005, p. 1-3.

[31] N Beyhan, B Kocyigit-Kaymakcioglu, S Gümrü and F Aricioglu. Synthesis and anticonvulsant activity of some 2-pyrazolines derived from chalcones. Arabian. J. Chem. 2017; 10, S2073-S2081.

[32] FA Oliveira, RND Almeida, MF Sousa, JM Barbosa-Filho, SA Diniz, IAD Medeiros. Anticonvulsant properties of N-salicyloyltryptamine in mice. Pharmacol. Biochem. Behav. 2001; 68, 199-202. 


\section{Appendixs}

Mass spectral of compound C1:

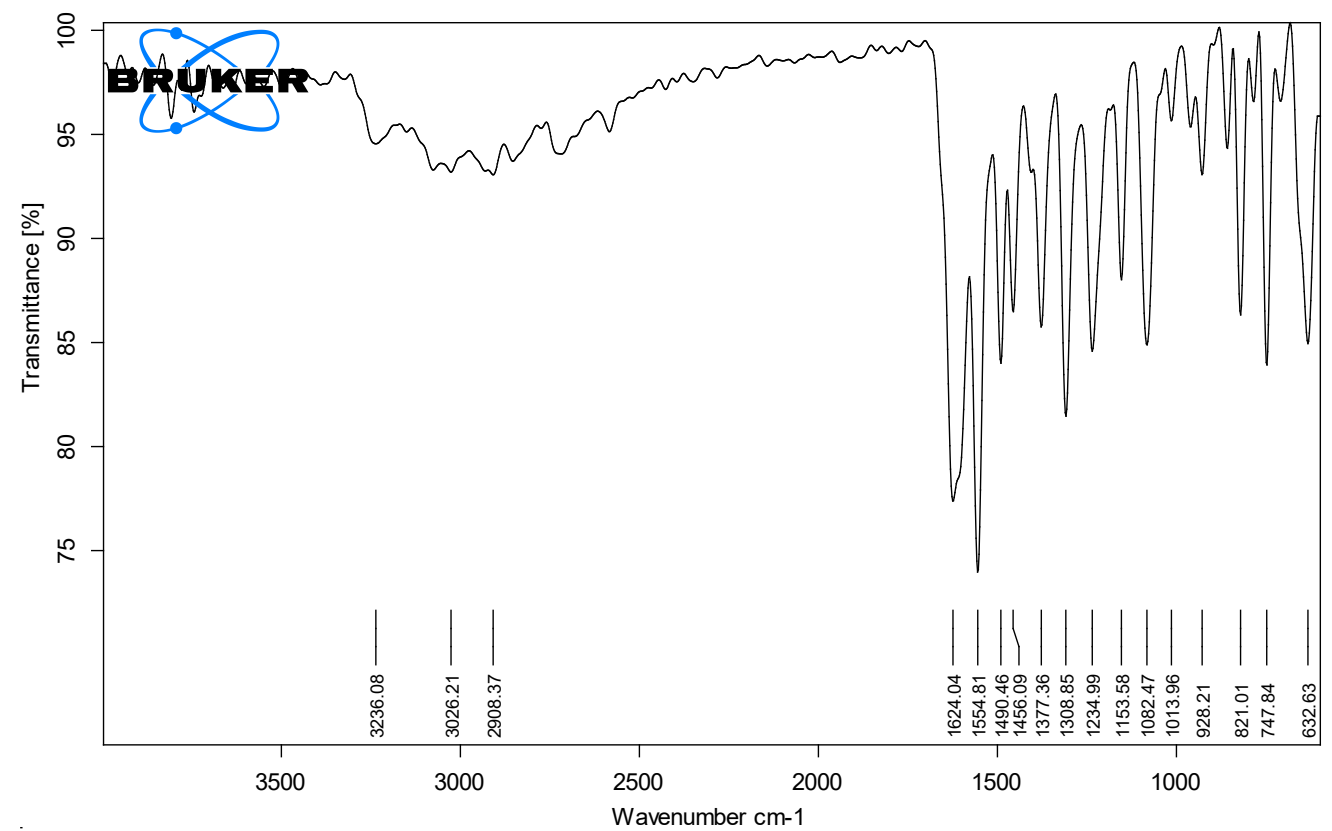

\begin{tabular}{|lll|l|}
\hline D:IFTIRIC1.1 $\quad$ Instrument type and / or accessory & $8 / 29 / 2020$ \\
\hline
\end{tabular}

Page 1/1

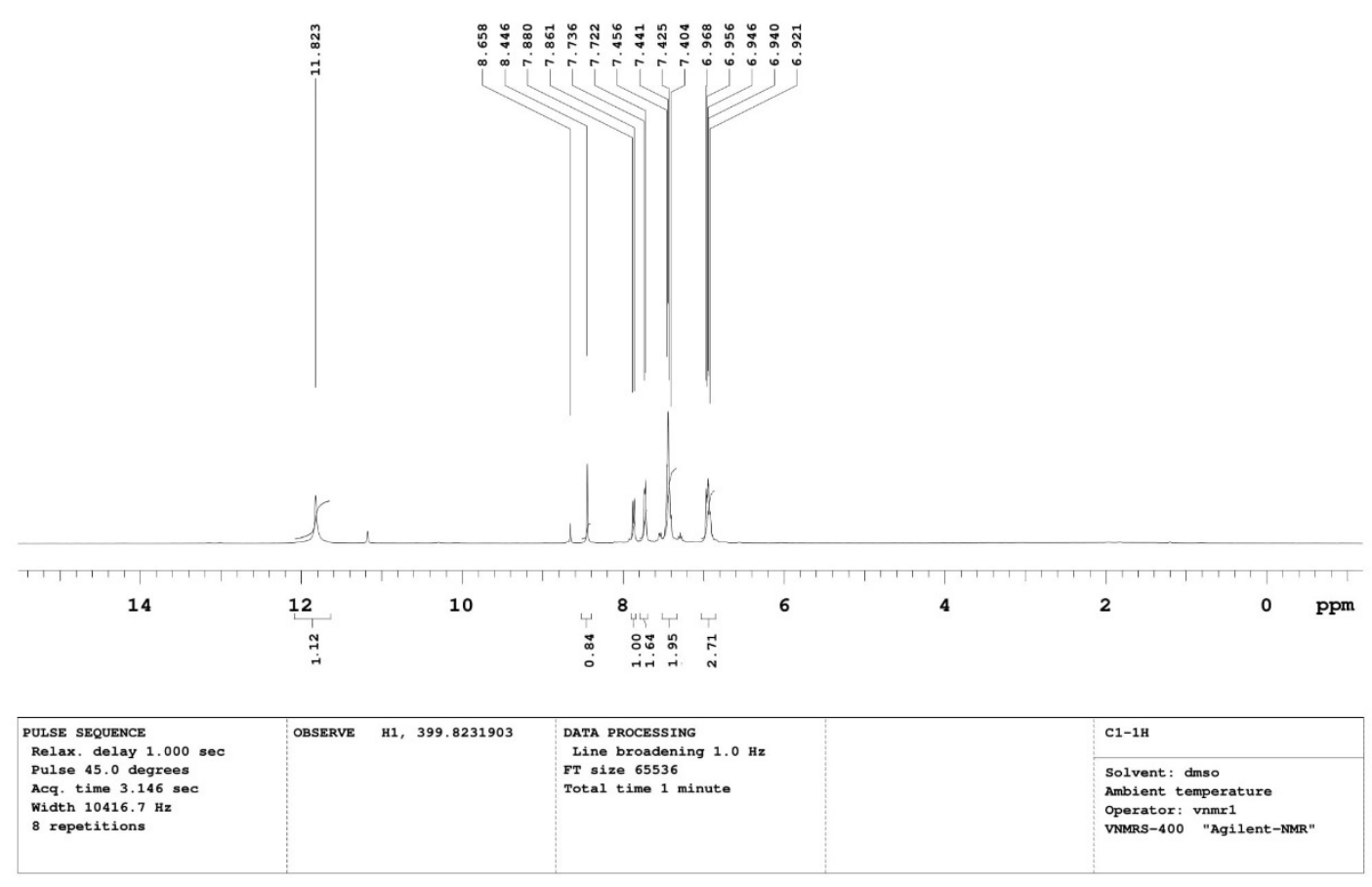




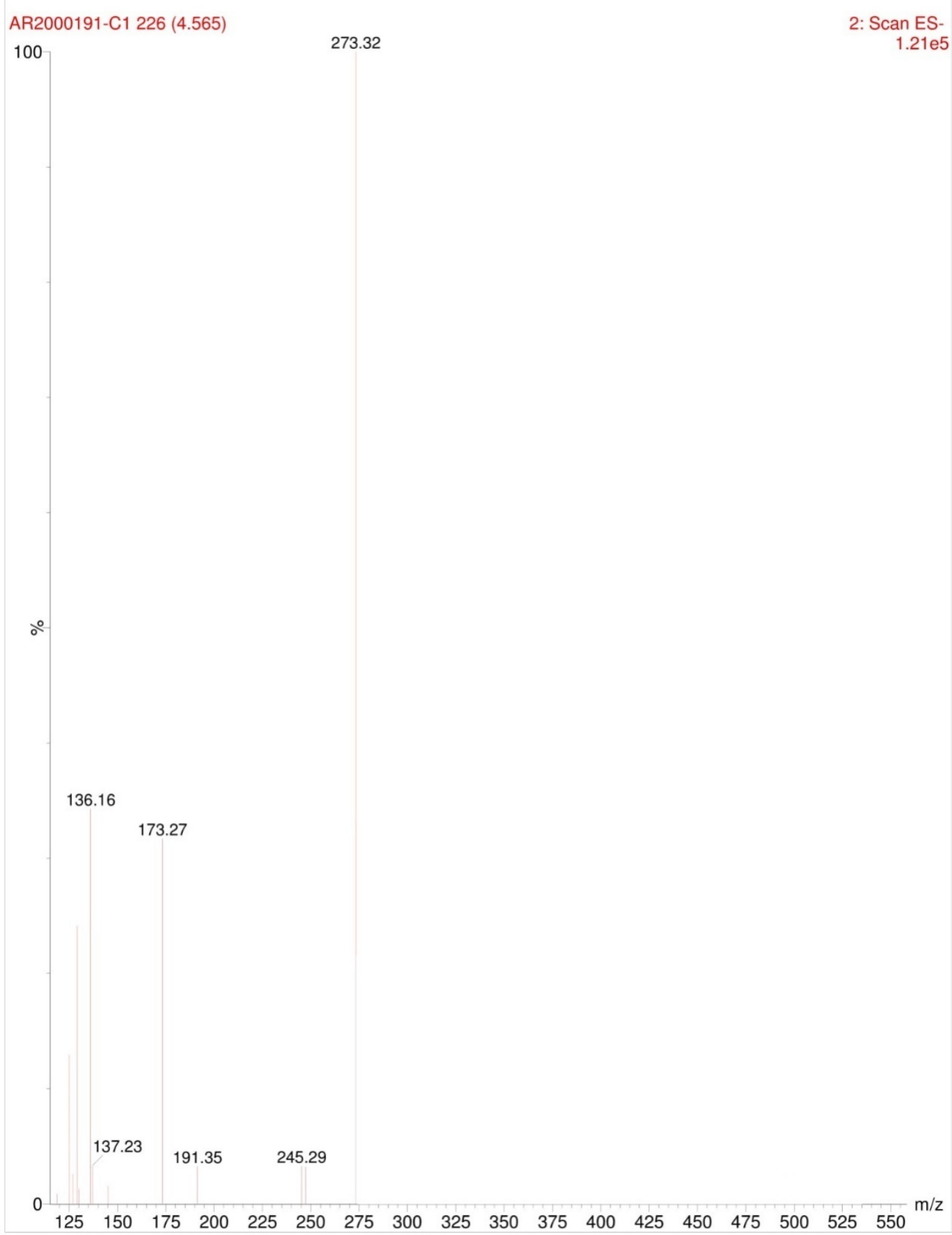


Mass spectral of compound C2:

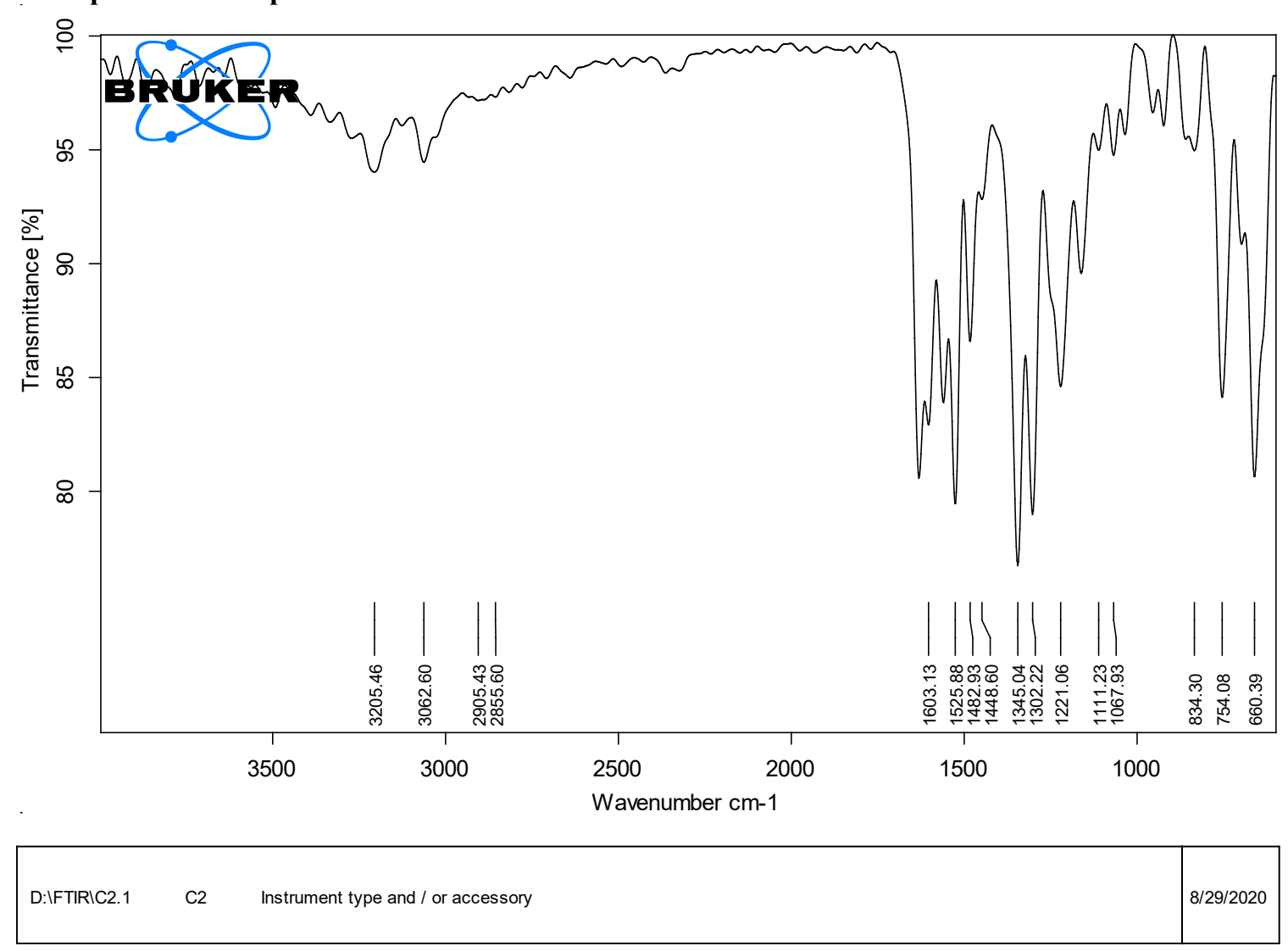

Page 1/1

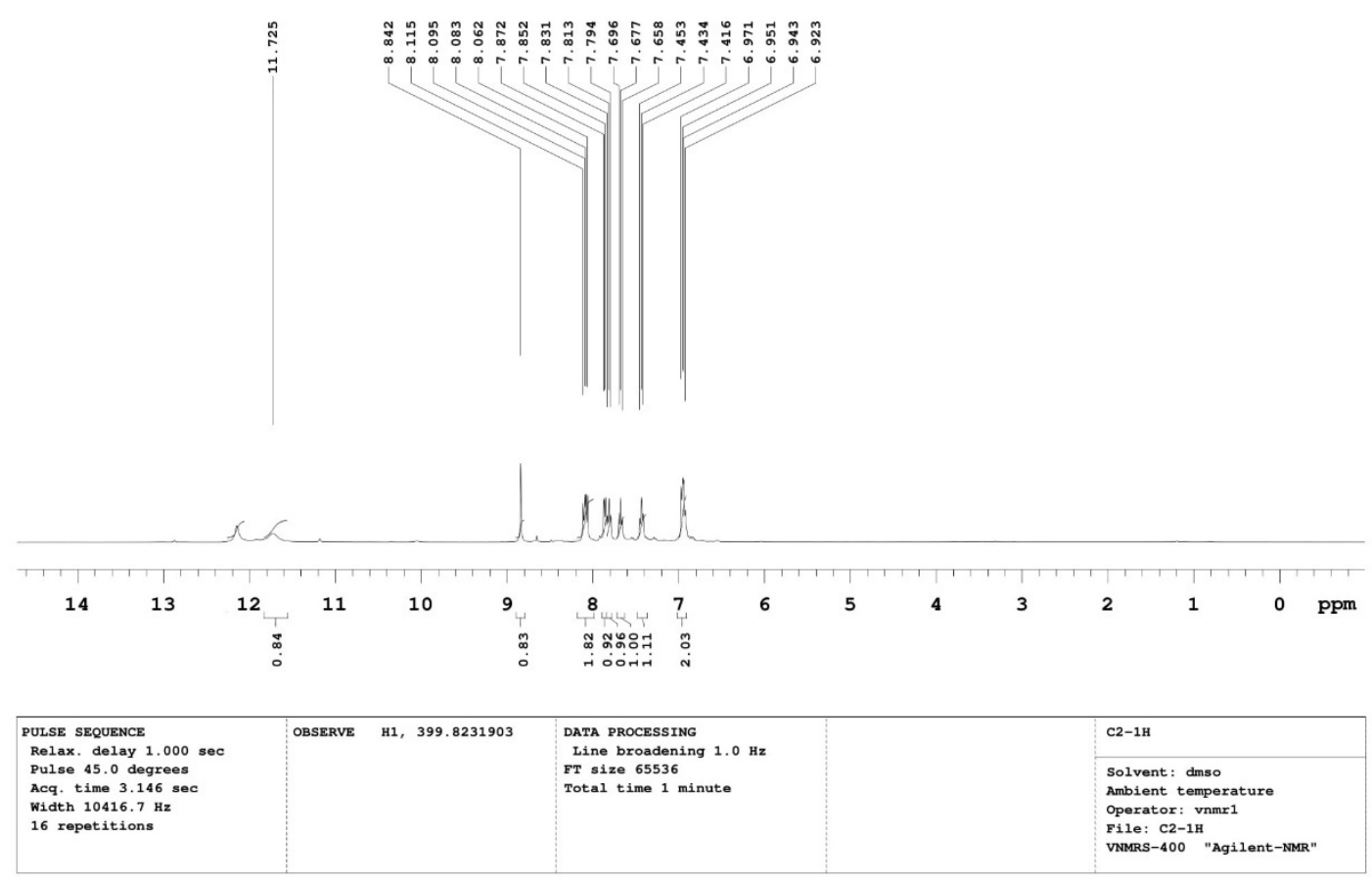




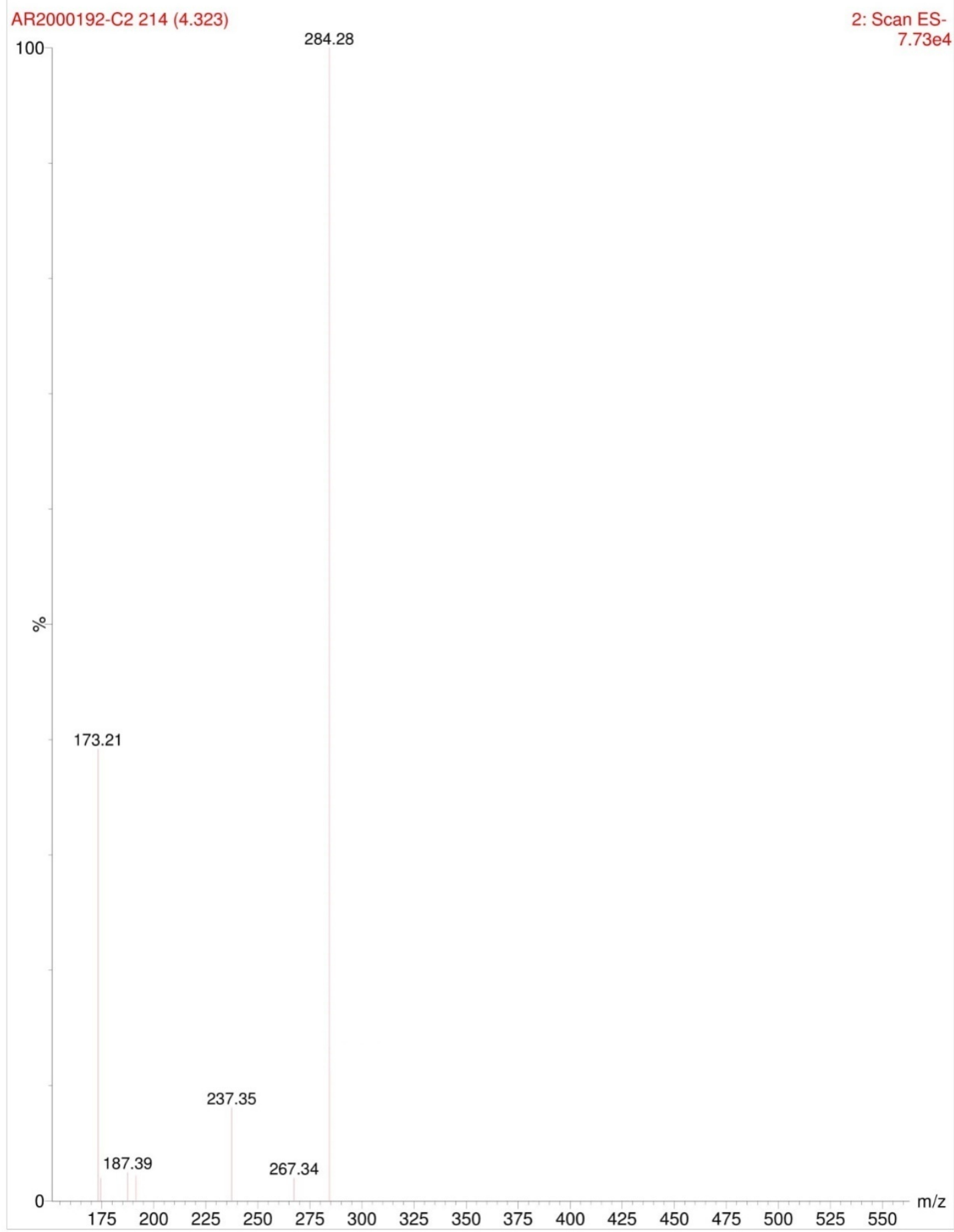


Mass spectral of compound C3:

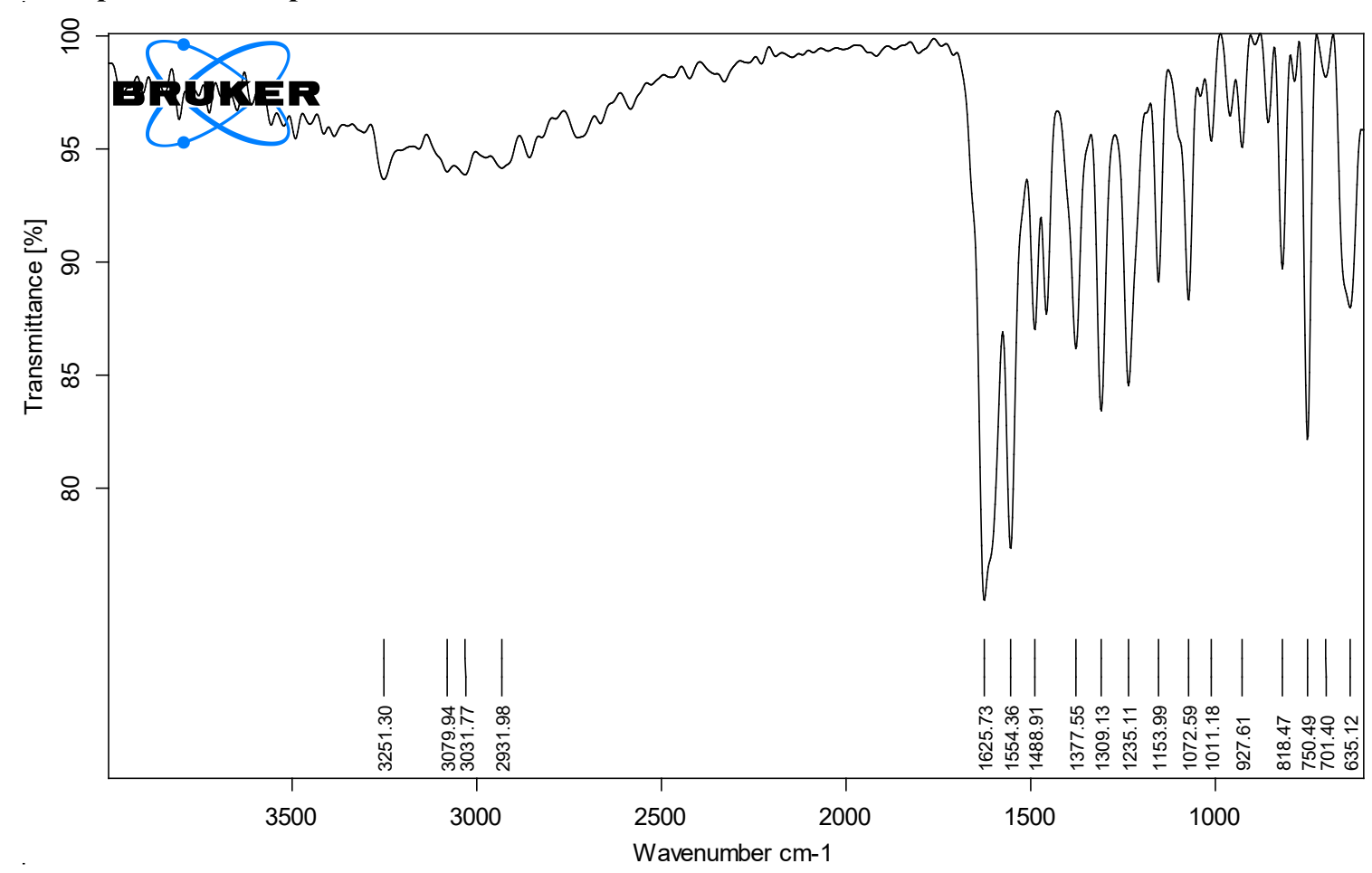

D:IFTIRIC3.1 C3 Instrument type and / or accessory

Page 1/1

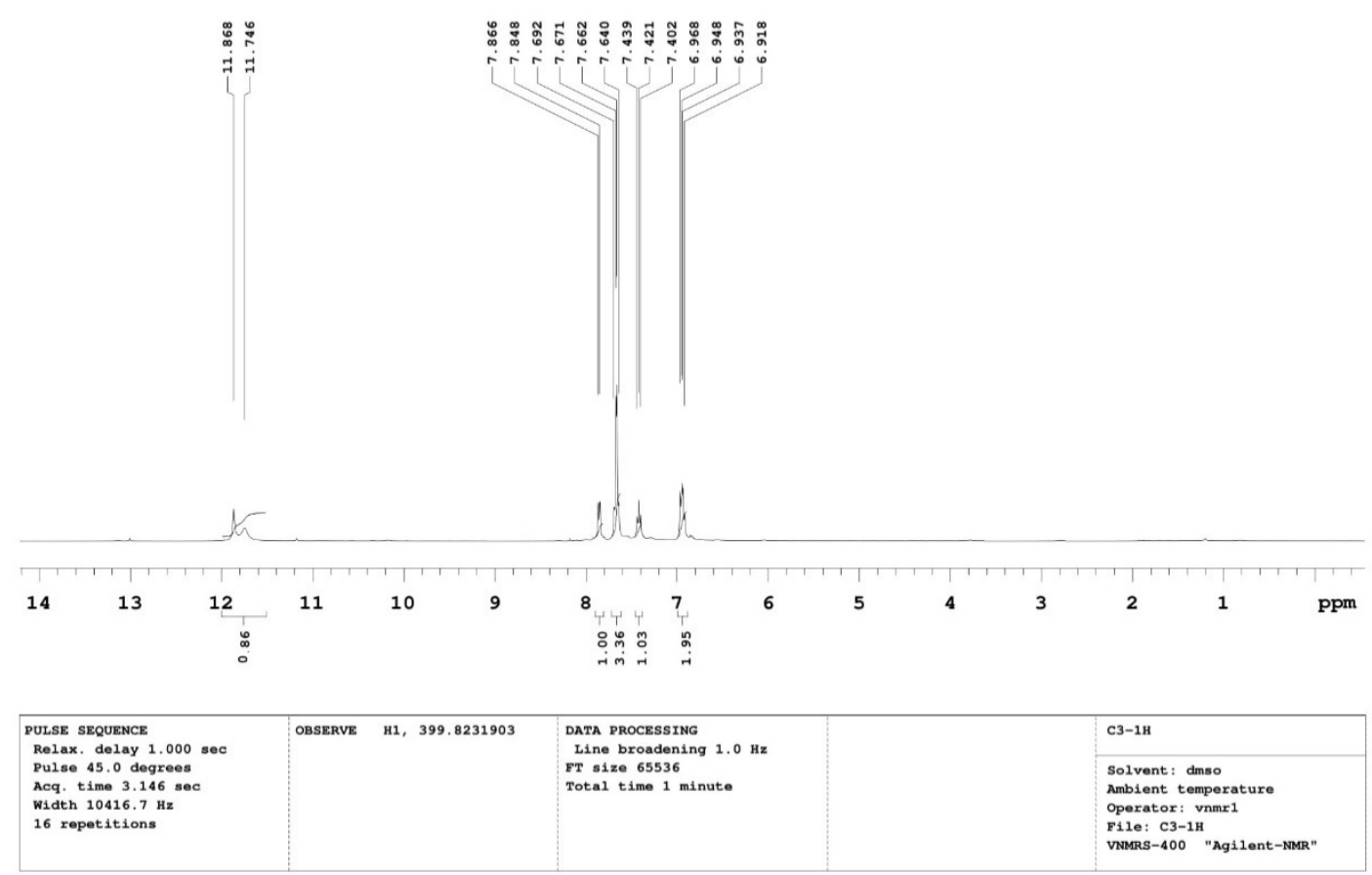




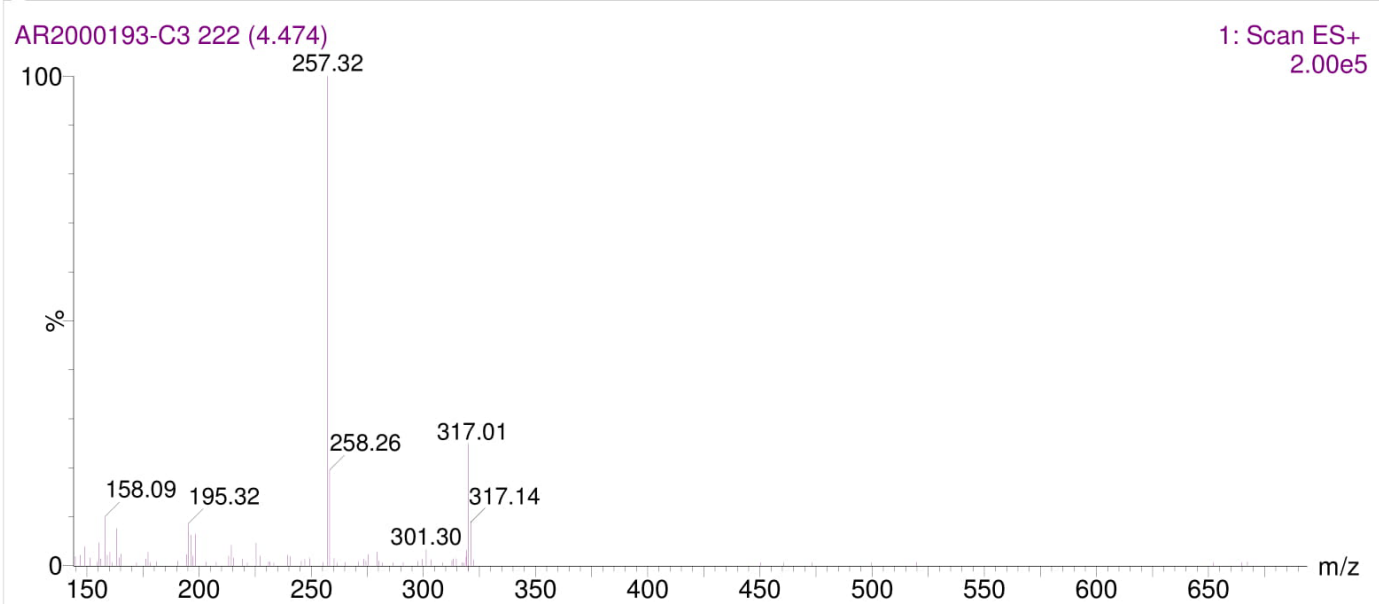

Mass spectral of compound C4:

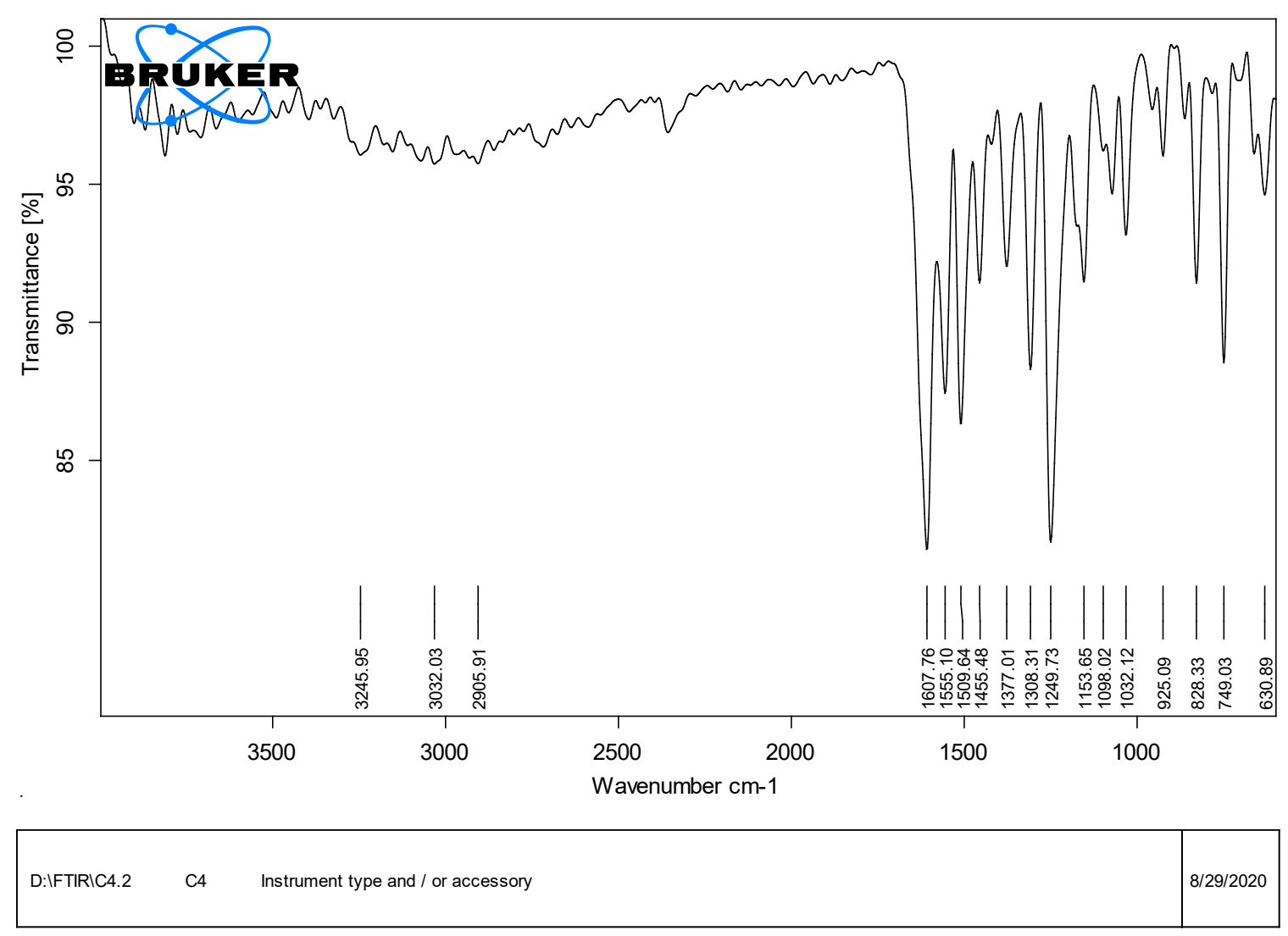

Page 1/1 


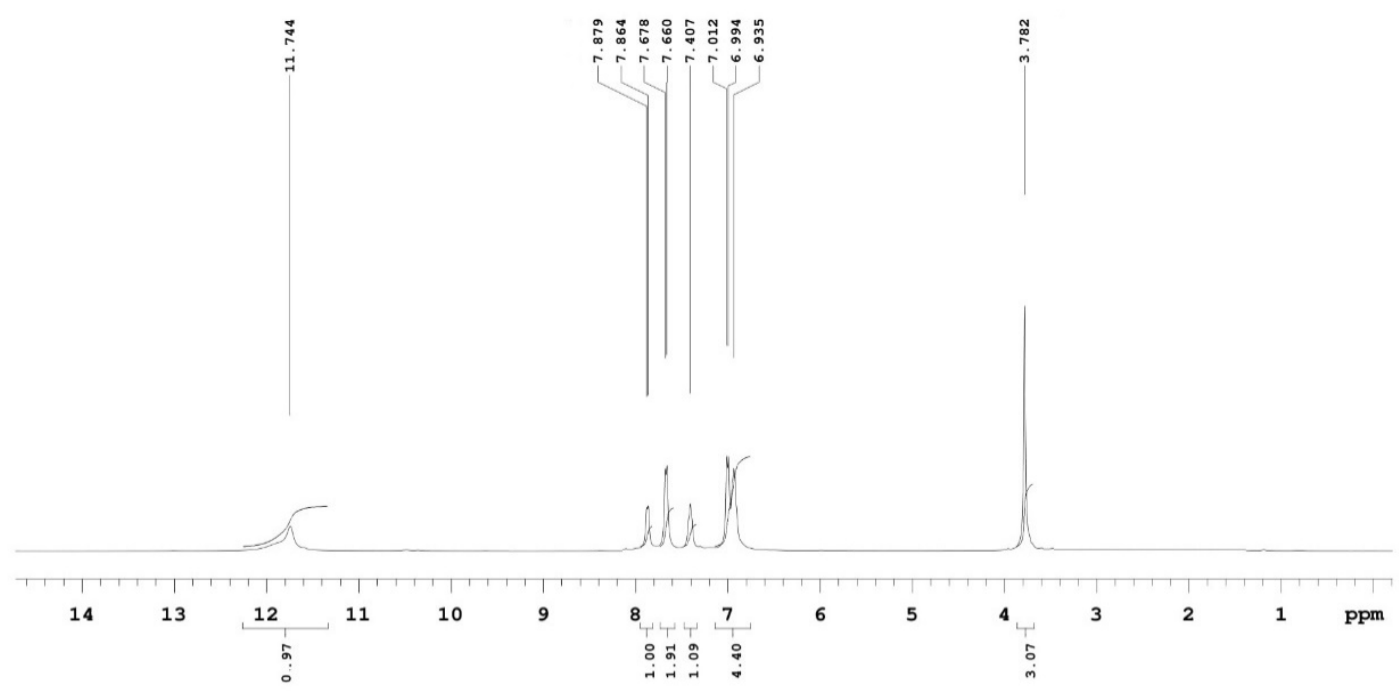

\begin{tabular}{|c|c|c|c|c|}
\hline \multirow{2}{*}{$\begin{array}{l}\text { PULSE SEQUENCE } \\
\text { Relax. delay } 1.000 \text { sec } \\
\text { Pu1se } 45.0 \text { degrees } \\
\text { Acq. time } 3.146 \text { sec } \\
\text { width } 10416.7 \mathrm{~Hz} \\
8 \text { repetitions }\end{array}$} & \multirow{2}{*}{\multicolumn{2}{|c|}{ OBSERVE H1，399.8231903 }} & \multirow{2}{*}{$\begin{array}{l}\text { DATA PROCESSING } \\
\text { Line broadening } 1.0 \mathrm{~Hz} \\
\text { FT size } 65536 \\
\text { Total time } 1 \text { minute }\end{array}$} & $\mathrm{C} 4-1 \mathrm{H}$ \\
\hline & & & & $\begin{array}{l}\text { Solvent: dmso } \\
\text { Ambient temperature } \\
\text { Operator: vnmr1 } \\
\text { File: C4-1H } \\
\text { VNMRS-400 "Ag11ent-NMR" }\end{array}$ \\
\hline
\end{tabular}

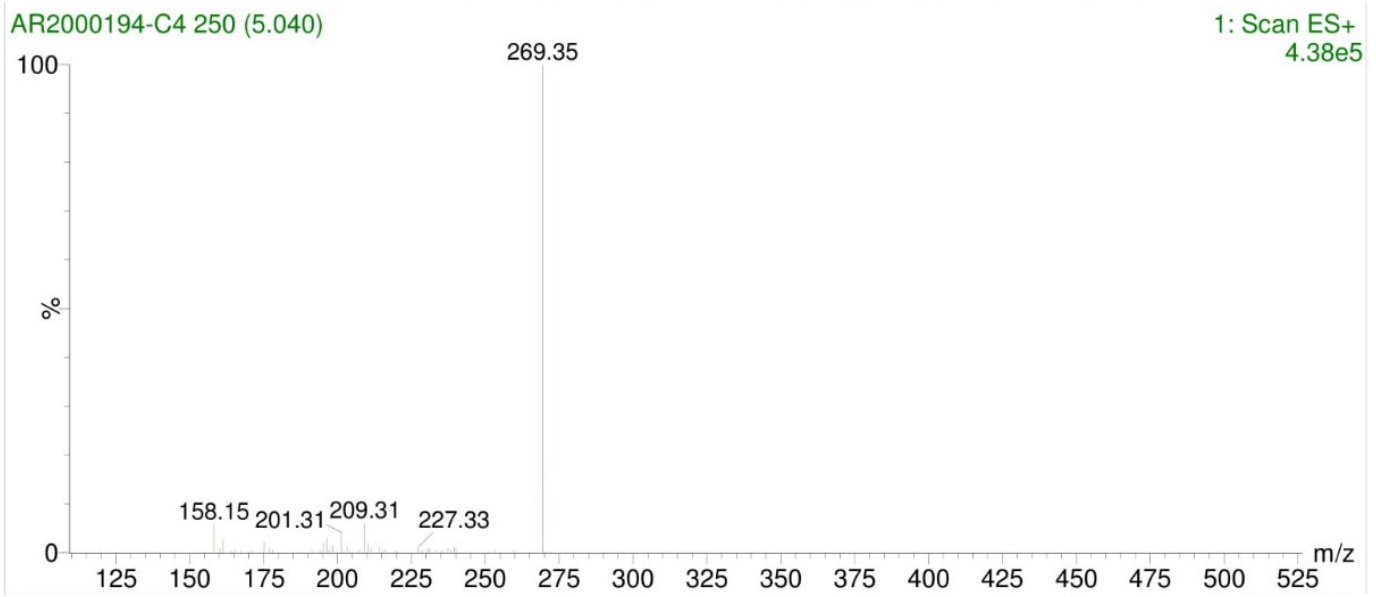




\section{Mass spectral of compound C5:}

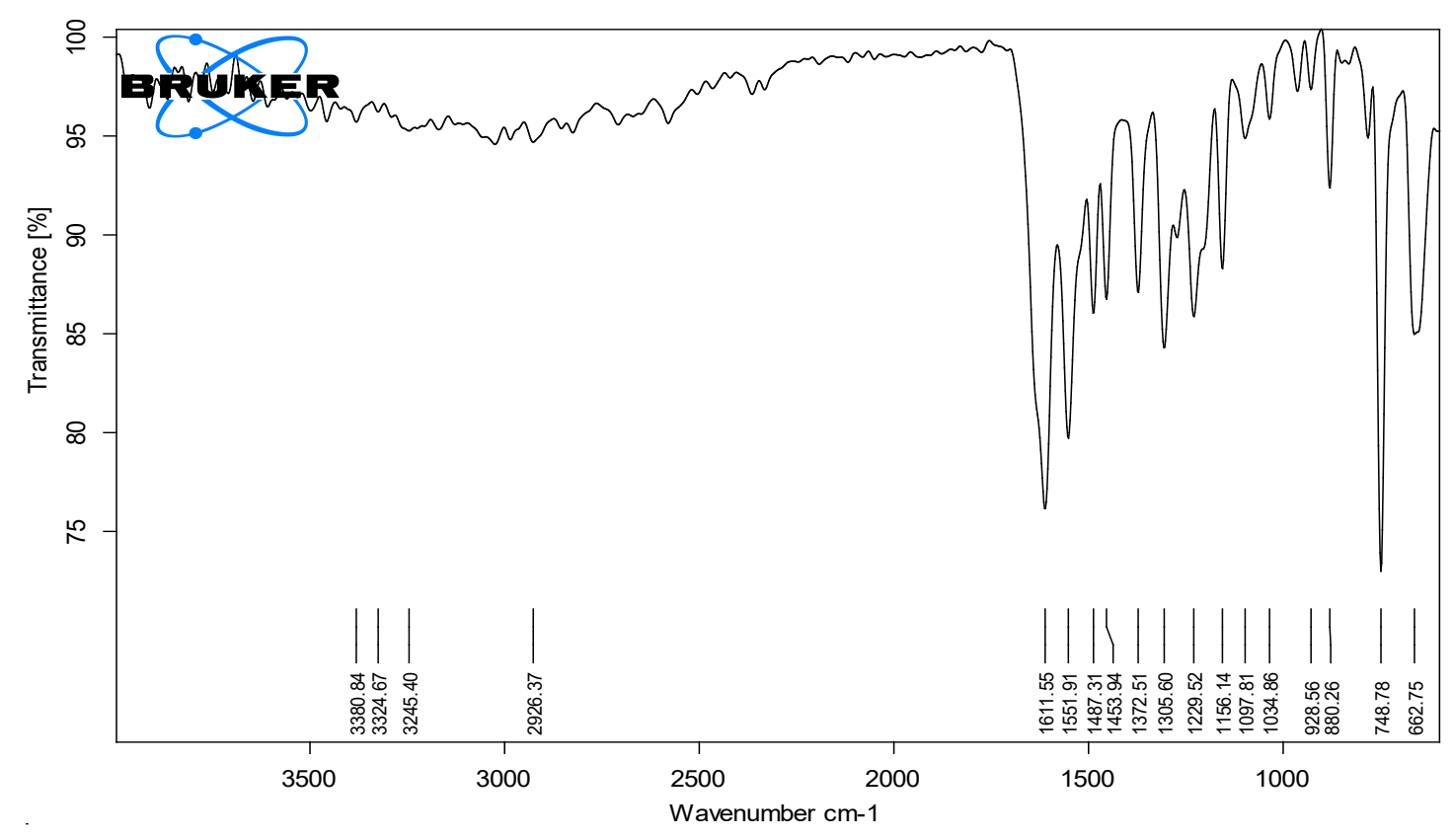

Page 1/1

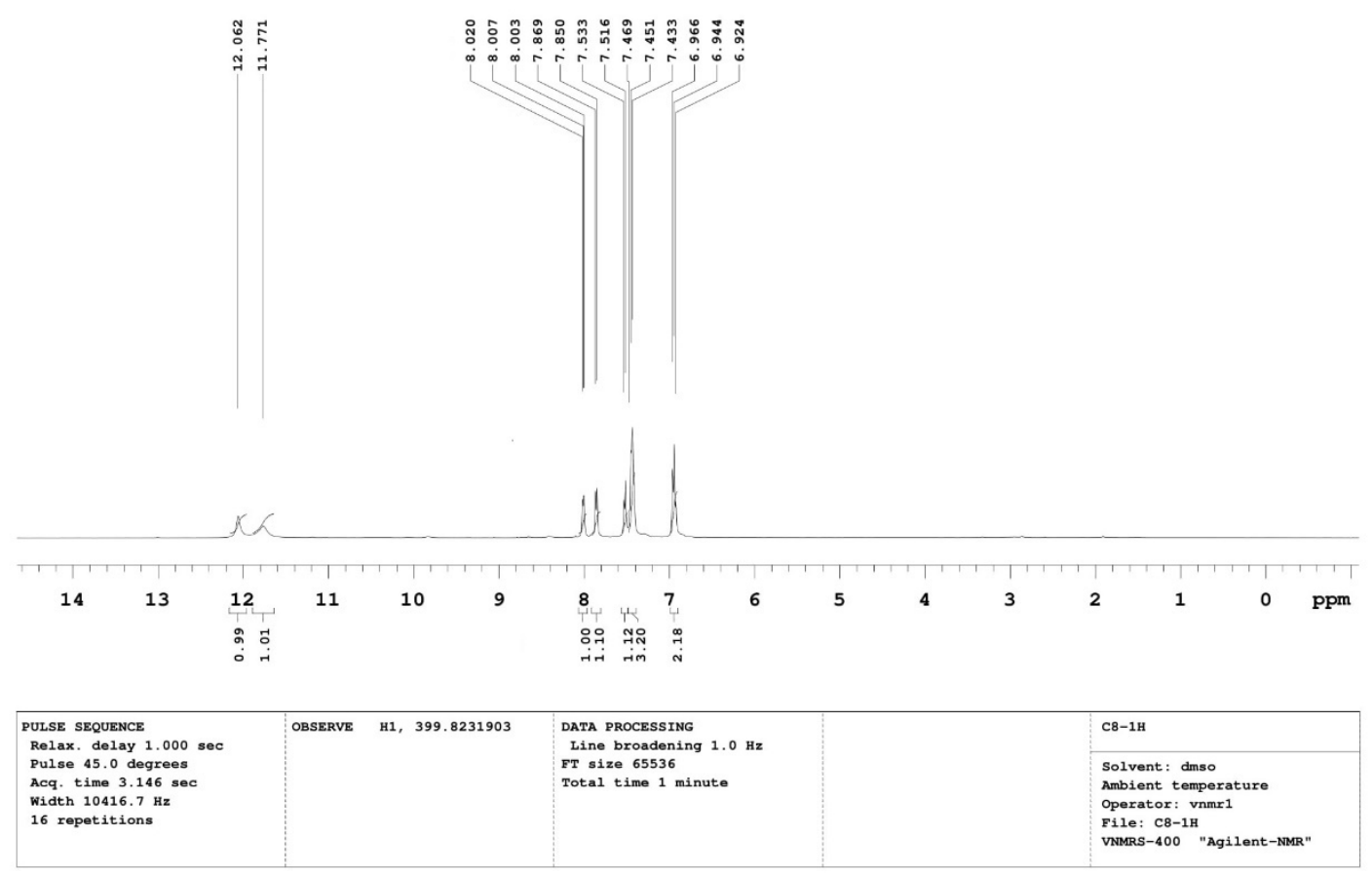




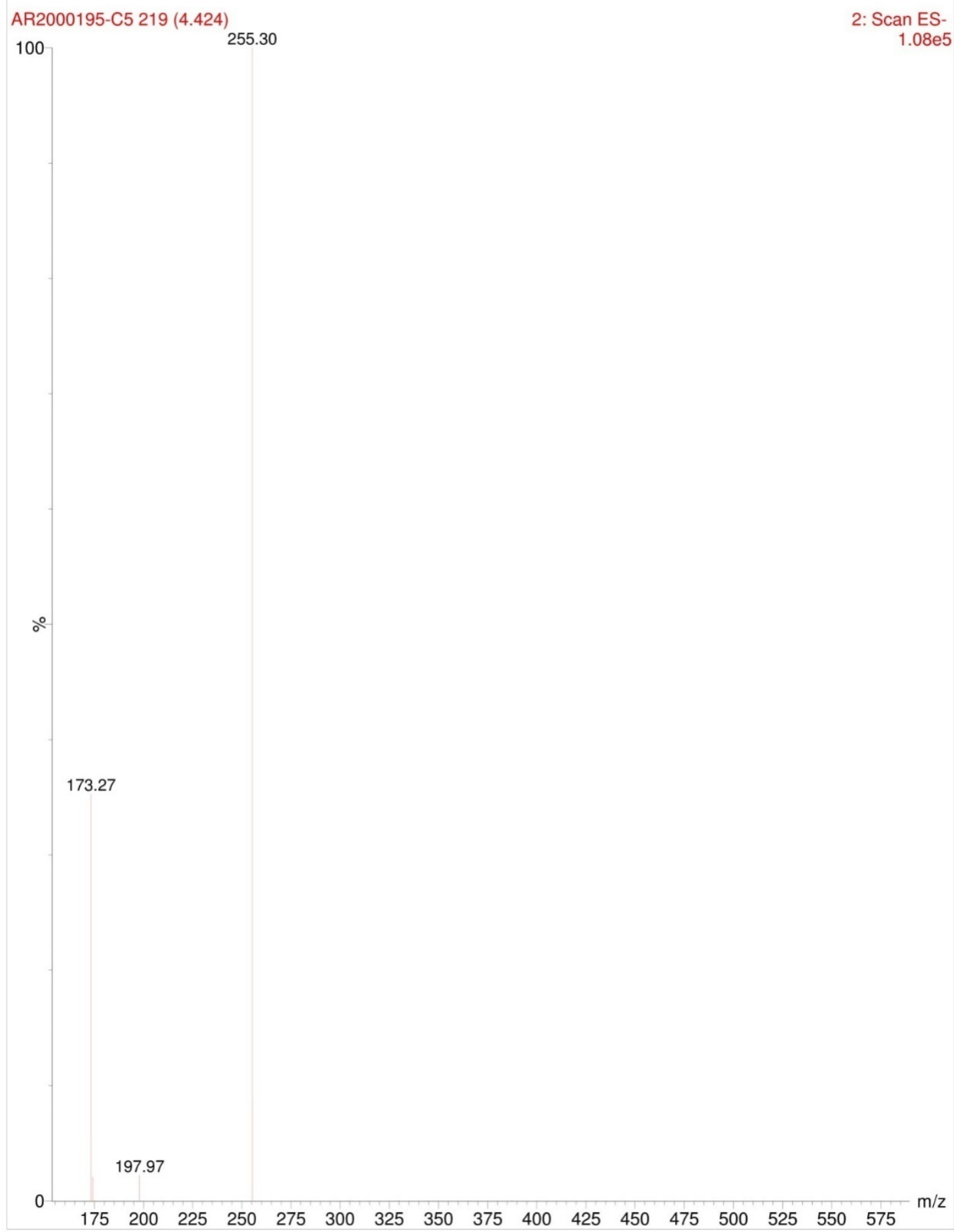

